\title{
Targeted Nanomedicines for Cancer Therapy, From Basics to Clinical Trials
}

\author{
Zahra Eskandari ${ }^{1,2}$, Fatemeh Bahadori², Burak Celik ${ }^{3}$, Hayat Onyuksel ${ }^{4}$ \\ ${ }^{1}$ Department of Chemistry, Biochemistry Division, Faculty of Sciences and Arts, Yildiz Technical University, Istanbul, \\ Turkey. ${ }^{2}$ Department of Pharmaceutical Biotechnology, Faculty of Pharmacy, BezmialemVakif University, Istanbul, \\ Turkey. ${ }^{3}$ Department of Pharmaceutical Biotechnology, Faculty of Pharmacy, BezmialemVakif University, Istanbul, \\ Turkey. ${ }^{4}$ Department of Biopharmaceutical Sciences, University of Illinois at Chicago, Chicago, IL USA.
}

Received, February 1, 2020; Revised, April 01, 2020; Accepted, April 27, 2020; Published, April 30, 2020.

\begin{abstract}
ABSTARCT - Traditional systemic chemotherapy involves the wide distribution of drug molecules in the body, causing toxic side effects in the healthy tissues and limiting the therapeutic dose required at the site of drug action. In order to decrease side effects and increase the drug efficacy, recent research on chemotherapy focuses on drug targeting. Targeted therapy can be achieved by several mechanisms including; 1) using an antibody as a drug that is specific to a disease biomarker, 2) using an antibody (or peptide) as a targeting agent conjugated to the drug molecule, 3 ) delivering the drug molecules to the target tissue in a nano-carrier with or without the targeting agent attached on its surface. The third approach involves the nanomedicines that can be targeted to diseased tissues by both passive (extravasating at diseased sites due to leaky vasculature) and active (specific interaction of the targeting agent with disease biomarker) targeting mechanisms. In this review we will cover the passively targeted nanomedicines prepared using nano drug carriers. Ideally the carrier particle should be in the right size $(1-100 \mathrm{~nm})$, stable enough to prevent drug leakage during circulation, and safe not to cause any damage to healthy tissues. Competition for all these properties generated many different types of materials to be used as nanodrug delivery systems. After a brief review of most commonly used drug carriers, we discuss the clinical use of the targeted nanomedicines with regard to their pharmacokinetic and pharmacodynamics properties, and how these properties vary from conventional formulations providing free drugs in the circulation after administration.
\end{abstract}

\section{INTRODUCTION}

In systemic drug therapy, the drug is distributed throughout the body via the bloodstream and only a small amount of the administered drug can reach the diseased tissue. Depending on the drug nature, drug molecules in the body may go to different regions in the body, dissociate in healthy tissues, interact with the neighbouring cells or be metabolized and excreted from the body. It is very common for the drug molecules that cannot reach their target to form toxic side effects. Treatment dose of the drug given to the body is adjusted according to these toxic effects. However, the expected pharmacological effect of the drug is dependent on the drug concentration in the diseased area and the dose required for complete treatment is not easily administered in some cases. For example, in the treatment of cancer, the drug is re-administered after the expected side effects are ameliorated. The administration of the drug in small and repeated doses constitutes immunity against drug in the cancer cells and causes more rapid proliferation of cancer cells compared to normal cells. In order to find a solution for this serious drug resistance problem, targeted treatment methods have been developed in recent years (1).
The aim of targeted therapy is to ensure that the drug molecules are concentrated predominantly in the affected area and distributed as little as possible to other parts of the body.

Drug targeting can be achieved in a variety of ways, such as using a molecule (or antibody) as a drug that directly interacts with a particular biomarker in one disease without interference with other tissues, linking the drug molecule to an antibody that directly interacts with a diseasespecific biomarker or loading drug molecules into a nano-carrier and sending them to the diseased tissue via passive and active mechanisms. In targeted therapy the effect of the drug increases as significant amounts of the dosage given is collected in the diseased area and unwanted side effects on other tissues are therefore reduced. With this approach, the possibility of using a higher drug dose and more effective treatment can be achieved. In addition, the patient's quality of life is greatly increased due to reduced side effects in targeted treatment.

Corresponding Author: Hayat Onyuksel, Department of Biopharmaceutical Sciences, University of Illinois at Chicago, Chicago, IL 60612-7231, USA; E-mail: hayat@uic.edu. 
This review briefly describes the different types of nanocarriers, their targeting methods to the desired regions in the body and how pharmacokinetic and pharmacodynamic properties of targeted nanodrugs differ from conventional drugs.

\section{NANOPARTICLES}

The term "nano" is derived from the Greek word "nanos", which means dwarf. One nanometer is equal to $10^{-9} \mathrm{~m}$ and the nanoparticles used in medicine are expected to have dimensions of 1-100 $\mathrm{nm}$. However, due to the difficulty of preparing particles at this size and the use of larger nanoparticles in the industry, according to the new scopes, materials with at least one dimension larger than 1 nanometer and smaller than 1 micron can be referred to as nanoparticles $(2,3)$. The nanoscale production of materials has positively influenced industrial fields such as agriculture, food and textile. Specifically, extraordinary progress has been recorded in medical applications of nanoparticles. Nanoscale materials can have a range of medical applications in drug delivery systems, imaging, implants and diagnoses (4). In addition, due to their functional and visual advantages including solubility improvement and possibility for topical application, nanoparticles' usage in cosmetic sector is becoming increasingly widespread (5).

Using nanotechnology and nano-carriers for the purpose of drug delivery has the following advantages:

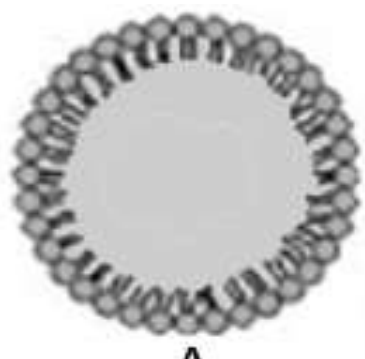

A

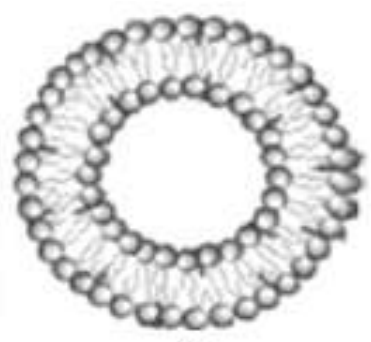

B

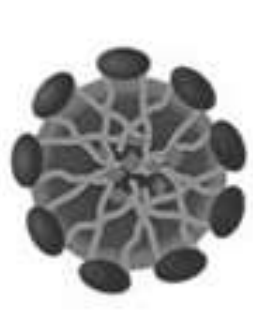

D
A: Development of drug characteristics:

- Increasing solubility and stability (6)

- Enhancing biodistribution and bioavailability as a result of targeted drug delivery (7)

B: Development of dose-dependent features:

- Decreasing applied dose

- Decreasing or even eliminating unwanted side effects

So far, various nanomaterials with the abovementioned characteristics have been developed to deliver drugs and currently new carriers are under investigation. Two different approaches are generally adopted in the preparation of nanoparticles: top-down and bottom-up.

In top-down method, large materials being of micron size are converted to nano size using different methods like milling, homogenization and sonication. However, in bottom-up method, the aim is to ensure that the substances at the molecular level rise to nanometer size through various methods such as chemical synthesis and self-assembly in solutions $(3,8)$.

Nanosized drug delivery systems and their properties that are frequently used and explored in health sciences are investigated in the following part. Fig. 1 presents the shapes of some of the nano drug delivery systems described in this review. Table 1 summarizes the uses and content of these nano drug delivery systems. 


\begin{tabular}{|c|c|c|}
\hline Nanoparticle & Material & Medical Uses \\
\hline $\begin{array}{l}\text { Liposomes, } \\
\text { Niosomes }\end{array}$ & $\begin{array}{l}\text { Phospholipids, } \\
\text { Non-ionic Surfactant }\end{array}$ & Drug / Gene delivery, Cosmetics \\
\hline Micelles & $\begin{array}{l}\text { Polymer, Phospholipid } \\
\text { Surfactant }\end{array}$ & $\begin{array}{l}\text { Drug / Gene delivery, Surface Cleaning, } \\
\text { Cosmetics }\end{array}$ \\
\hline $\begin{array}{l}\text { Nanoemulsions, } \\
\text { Microemulsions }\end{array}$ & $\begin{array}{l}\text { Lipid + Surfactant, } \\
\text { Lipid + Surfactant + Co- } \\
\text { surfactant }\end{array}$ & Drug / Gene delivery, Cosmetics \\
\hline $\begin{array}{l}\text { Solid Lipid Nanoparticles, } \\
\text { Nanostructured Lipid Carriers }\end{array}$ & $\begin{array}{l}\text { Solid Lipid + Stabilizer, } \\
\text { Solid Lipid + Liquid, Lipid + } \\
\text { Stabilizer }\end{array}$ & Drug / Gene delivery, Cosmetics \\
\hline Dendrimers & Branched Polymer & Drug / Gene delivery, \\
\hline Polymeric Nanoparticles & Polymer & Drug / Gene delivery, \\
\hline Nanocrystals & Drug & High Dose Drug Delivery \\
\hline Quantum Dots & Cdse, Zns, Inas, Pbs, Gan & Imaging \\
\hline Carbon-Based Nanoparticles & Carbon & Drug / Gene delivery, \\
\hline Metallic Nanoparticles & $\begin{array}{l}\text { Gold, Silver, Iron Oxide And } \\
\text { Similar Metals }\end{array}$ & $\begin{array}{l}\text { Imaging, Drug / Gene delivery, } \\
\text { Photothermal or Magnetic Therapy }\end{array}$ \\
\hline
\end{tabular}

\section{Liposomes}

Liposomes are spherical vesicular systems with an inner aqueous core and lipid bilayer structure with a size of $0.02-3.5 \mu \mathrm{m}$. They are usually prepared with amphiphilic phospholipid molecules. Addition of various sterols, especially cholesterol, to the bilayer structure increases the stabilization of liposomes and drug delivery capacity. Liposomes show structural similarity to phospholipids or lipoproteins found naturally in cell membranes. Due to these properties, liposomes are biologically compatible and can be degraded in the body and do not lead to serious toxic effects. Oxidation and hydrolysis of lipids during storage time and the tendency of the particles to grow together over time are among the common stability problems of liposomes $(10,11)$.

With the aim of avoiding these stability problems, nisosomes have been emerged as an alternative drug delivery system that can also provide an economical alternative to the high cost of phospholipids. Niosomes are vesicular systems, prepared with double layers of non-ionic surface active materials with methods similar to liposomes. The toxic effects of surfactants in the structure and the risk of fusion and aggregation during storage are among the disadvantages of nisosom-based systems (12).

Liposomes are used to enhance the solubility, bioavailability, systemic retention, or tissuerelated distribution of encapsulated drugs (13-15). Liposome-based treatments are known to broad the therapeutic window significantly. Especially in oncology, these drug delivery systems are very effective due to their selective targeting to the solid tumors (16-19).

For example, Hempel et al. investigated pharmacokinetics of daunorubicin and Daunoxome $^{\circledR} \quad$ (liposomal daunorubicin) in children. Data was reported to best be described by a one compartment model. Clearance was found to be $6.41 \mathrm{ml} \mathrm{h}^{-1} \mathrm{~kg}^{-1} \pm 0.551 \%$ and volume of distribution $65.4 \mathrm{ml} \mathrm{kg}^{-1} \pm 0.5$. The area under the curve at a dose of $60 \mathrm{mg} \mathrm{m}^{-2}$ was $231 \mathrm{mg}^{-1} \mathrm{~h}$. Overall, DaunoXome ${ }^{\circledR}$ showed prolonged retention, increased target distribution, equivalent efficacy, and reduced toxicity in comparison with Daunorubicin (20).

Cytarabine is the active ingredient of DepoCyt. In treatment with DepoCyt ${ }^{\mathbb{Q}}$, tumour exposure to the cytotoxic concentration and response rate increased while toxicity decreased. Similarly, a decrease in toxicity was observed in Doxil ${ }^{\circledR}$ and Myocet $^{\circledR}$, retention and target distribution were increased and an equal efficacy with Doxorubicin was achieved. In Marqibo ${ }^{\circledR}$, even a superior efficacy in comparison with the active substance, Vincristine, was observed. These kinds of advantages are mentioned for some other approved liposome formulations like Vyxeos ${ }^{\circledR}$, Onivyde ${ }^{\mathrm{TM}}$ and Mepact ${ }^{\circledR}$.

Batist compiled cardiac safety of liposomal anthracyclines (21). Despite very striking clinical efficacy of this chemotherapy agents, synergistic cardiac toxicity limits the application. Liposomal encapsulation is a strategy to deliver these drugs 
while keeping heart safe from the side effects. Stability, drug release rate, and in pharmacokinetic properties, such as blood circulation time, sites of deposition of the liposome are mentioned as advantages (22).

In a series of clinical trials, Doxil/Caelyx has been shown to have significant efficacy in breast cancer treatment with reduced cardiac toxicity (23).

Myocet (non-pegylated liposomal doxorubicin) was compared to equivalence dose of free doxorubicin in breast cancer in two randomized trials $(24,25)$. The formulation enhanced the anti-tumour efficacy and lowered the cardiac toxicity. Table 3 gives more examples of liposomal formulations.

\section{Micelles}

Micelles are small size (5-100nm) particles formed by spontaneous assembly of polymeric or lipidbased amphiphilic molecules in the aqueous media, without requiring any external energy. The interior part of spheriods is hydropobic and serves as a carrier for oil soluble drugs and the outer part is hydrophilic $(26,27)$. Amphiphilic molecules form micelles in the aqueous medium only after reaching a certain concentration and aggregation may happen in this process so that the free energy of the system is reduced. This threshold concentration value is called the critical micelle concentration (CMC) and differs depending on the structure of amphiphilic molecules. Systems with a low CMC are more resistant to dilution. When an aqueous dispersing system containing a micelle is diluted with water, the concentration of amphiphilic molecules present as monomer in the system is reduced and the micelle is broken down to the amount required to restore the concentration to the $\mathrm{CMC}$ value. In this case, the drug loaded into the micelles also releases in the aqueous medium. After injection and contact with large blood volume, micelles with high $\mathrm{CMC}$ may cause precipitation with sudden release of the drug, which may result in embolism. Because of these reasons, low $\mathrm{CMC}$ values are preferred in treatments.

Micelles are preferred drug carriers because they are easy to prepare, able to carry high amounts of drug, highly stable in their structure and modifiable to serve different purposes (27). In addition, micelles prepared by phospholipids demonstrate an acceptable toxicity profile (28).

Genexol-PM and Nanoxel-PM are micellar formulations that were approved in South Korea. In their study, Kim et al. (29) compared GenexolPM with conventional paclitaxel. They found
Genexol-PM advantageous to paclitaxel due to lack of necessity for pre-medication and ability to deliver more drugs with no extra toxicity.

Lee et al. (30) developed and evaluated Nanoxel-PM in comparison with its conventional form, Taxotere ${ }^{\circledR}$. In studies in rats, mice and beagle dogs, Nanoxel-PM showed similar pharmacokinetic profiles to Taxotere $^{\circledR}$ and unmetabolized docetaxel was found to be the same in both cases in excreted drug in faeces or urine. Comparable efficacy was achieved with pharmacokinetic bioequivalences in lung cancer in vivo and lung, ovary and breast cancer cell lines. Also, similar toxic effects are reported in related studies. Table 4 shows more information on similar micelle formulations.

\section{Nanoemulsions}

Nanoemulsions are drug delivery systems, usually $10-200 \mathrm{~nm}$ in size, prepared by homogeneous distribution of two incompatible liquid phases. A variety of amphiphilic surfactants are added to the formulation and mechanical shear is used to provide emulsion formation. Based on the desired application, nanoemulsions can be prepared as oil in water $(\mathrm{O} / \mathrm{W})$ or water in oil $(\mathrm{W} / \mathrm{O})(31,32)$.

The nanosize of the emulsions that have oil droplets in their internal phase allows the parenteral application of oil soluble drugs and various vitamins. The most common stability problem in $\mathrm{O} / \mathrm{W}$ nanoemulsions is the Ostwald repening and the dissolving of small sized particles of the system in the outer phase and their participation in the formation of larger particles over time.

Flocculation is more commonly seen in W/O emulsions and is known as the association of small particles with large particles and the increase in particle size.

The relatively low amount of surfactant required for the preparation of emulsions, their applicability in the form of cream, spray, foam and lotion and their resilience against dilution and $\mathrm{pH}$ changes are among the advantages of these systems (32).

Microemulsions are also colloidal dispersions with a droplet size of 5-200 $\mathrm{nm}$. They are formed spontaneously by mixing high amounts of surfactant and co-surfactant without any need to external energy. Triangular phase diagrams are often used to determine the necessary amounts of surfactants during the preparation process. Microemulsions are thermodynamically stable, but the high level of surfactant present in the structure can lead to various side effects (33). 
An example of this type of nanoformulation is Oncaspar ${ }^{\circledR}$. Oncaspar ${ }^{\circledR}$ was approved by EMA in 2016 to treat Acute lymphocytic leukemia (ALL). Panetta et al. (34) checked the pharmacokinetics and pharmacodynamics of Asparaginase and PEG Asparaginase (Oncaspar ${ }^{\circledR}$ ) in ALL. The clearance of native asparaginase was much higher than that of PEG asparaginase. They found significant pharmacokinetic and pharmacodynamic differences due to asparaginase preparation for example VMAX decreased from 122 to 61 $(\mu \mathrm{M} /$ days $) /(\mathrm{IU} / \mathrm{mL}), \mathrm{KmCSF}$ from 3.6 to $1.1 \mu \mathrm{M}$ and kin (1/days) (4.8 to 1.0$)$ by PEGylation.

A nanoemulsion of 5-Aminolevulinic acid is in clinical trial for superficial basal cancer cell photodynamic therapy (35). Three photosensitizers are compared in phase 2 . The photodynamic is joined with aminolevulinic acid nanoemulsion $\left(\mathrm{BF}-200\right.$ ALA/Ameluz $\left.{ }^{\circledR}\right)$ and two other compounds.

The nanoemulsion is $7.8 \%$ of 5 -aminolevulinic acid and in order to rise the affinity towards epidermal tissues soy phosphatidylcholine and propylene glycol are used (36). The clinical trial status is Active. The same formulation was used for treatment of lentigo maligna (NCT02685592) and some other skin disorders like multiple actinic keratosis (NCT01893203) and actinic keratosis (NCT01966120 and NCT02799069).

\section{Lipid nanoparticles}

Lipid nanoparticles can be of two types, namely solid lipid nanoparticles (SLN) and nanostructured lipid carriers (NLC). SLNs are disperse systems of $50-1000 \mathrm{~nm}$ size, prepared by stabilizing various solid lipids using different surfactants in an aqueous environment. NLCs are a new generation of lipid nanoparticles, which contain liquid lipid in core surrounded by solid lipid. Fatty triglycerides, fatty acids, sterols and various waxes are used as solid fat, while oleic acid and vegetable triglycerides with medium chain length are generally preferred as the liquid lipid.

Depending on the production method and the nature of the lipids used, the active substance may be dispersed in the matrix or it may be present in the core or shell part. Release from particles also varies according to the medium in which the drug is present. When the drug molecules accumulate on the surface, a rapid release is observed while the drug molecules trapped in the inner part exhibit a slower and controlled release. SLNs generally have less drug loading capacity than NLCs due to the lipid phase density. Leakage of the drug from carrier over time and different colloidal constructions that may be present in the environment after production are among the disadvantages of these systems. Nonetheless, lipid nanoparticles are preferred because of their low toxicity, the absence of organic solvents during their preparation and their stability for large scale production and sterilization $(37,38)$.

Liu et al. (39) reported successful avoid of resistance to paclitaxel in breast cancer cells by delivering miRNA-200c in cationic SLNs. SLNs transfected the MCF-7 cells more effectively than Lipofectamine or the free miRNA-200c without changing morphology and environment of the cells. They concluded that this treatment can improve IC50 of paclitaxel and delivery of miRNA in breast cancer treatment.

Ji et al. (40) used SLNs to deliver naringenin. Although naringenin didn't affect the viability of A549 cells, naringenin-SLN presented high cellular uptake. In biodistribution studies in rats, intratracheal instillation administration of naringenin-SLN improved pharmacokinetic parameters like mean residence time and maximum plasma concentration.

In another study, folic acid functionalized SLNs was used for oxaliplatin delivery for treatment of colon cancer. Functionalized SLNs showed the best anticancer potential in comparison to nonfunctionalized SLNs and free drug (41).

\section{Dendrimers}

Dendrimers are spherical synthetic constructs consisting of functional groups branching around the nucleus. Dendrimer name is derived from the word "dendro", which means "tree" in Greek. Dendrimers are classified by different generation numbers which refer to the number of repeated branching cycles that are performed during their synthesis. As the number of branching points increases, the molecule size increases as well.

Drug delivery in dendrimers occurs by the encapsulation of the drug in the denderimeric structure or by the interaction with the functional groups on the surface. Through modification of these groups, hydrophobic or hydrophilic types of the molecule can be prepared and various ligands can be added for targeted drug delivery. The molecule size and weight of the dendrimers can be controlled as desired during product synthesis and it is possible to design them for different applications. However, multiple stages in the production of bigger molecules increase costs and make the industrial production difficult on larger scales (42). In addition, toxicity profiles of dendrimers in the body must be taken into consideration. 
Dendrimers are known to be able to enhance the uptake by cells, bioavailability and therapeutic efficacy. They also can optimize the biodistribution and intracellular release profile. Clearance and degradation rate of attached drugs and toxicity are reported to be reduced (43). Although there is not any approved dendrimer formulation by FDA or EMA, there are some formulations in clinical trials. For example, DTXSPL8783 is a docetaxel (DTX)-dendrimer conjugate in phase 1 study in patients with advanced solid tumours in UK (44)

Several dendrimeric formulations are reported to be successful in vitro and vivo experiments. For example, Al-Jamal KT (45) reported the use of a cationic poly-L-lysine dendrimer complexes of doxorubicin compared to the free DOX. The complex is reported to show better penetrability into monolayers than the multicellular tumour spheroids, and in vivo tumors than the free drug. Toxicity was reduced significantly in complexation use.

Han et al. (46) used a combination of chemotherapy and gene therapy for the treatment of liver cancer. A T7-conjugated polyethylene glycol-modified polyamidoamine dendrimer (PAMAM-PEG-T7) was used as a carrier to co deliver doxorubicin and the therapeutic gene encoding human tumor necrosis factor-related apoptosis-inducing ligand (pORF-hTRAIL). In Bel-7402 cells, T7-modified system had higher uptake and gene expression than unmodified system. Higher accumulation and efficiency was observed in vivo as well in comparison with free DOX or pORF-hTRAIL.

In another study, PAMAM-based dendrimers were used by Lee et al. (47) as vehicles to combine chemotherapy and immunotherapy for prostate cancer. They reported that the system with $\mathrm{CpG}$ oligonucleotides (ONTs) as immune-stimulants and doxorubicin as chemotherapeutic agent showed much lower toxicity than the same dose of free Dox in in vivo murine tumour models.

\section{Polymeric nanoparticles}

Polymeric nanoparticles, as the name implies, are drug delivery systems prepared with different polymers. The polymers used can be classified as biodegradable or non-biodegradable. The first class contains natural polymers (e.g., gelatin, chitosan) and the second class includes synthetic polymers (e.g., polylactic acid and PLA). Where non-biodegradable polymers are used, those having low toxicity such as polyethyleneglycol (PEG), polyvinylpyrrolidone (PVP) and carboxyl methyl cellulose (CMC) are generally preferred for medical applications (48).

Polymeric nanoparticles can be prepared in different forms such as nanospheres and nanocapsules. Commonly used nanospheres are spherical drug delivery systems composed of a polymeric matrix. Drug delivery occurs by erosion and/or diffusion depending on the nature of the polymer. Nanocapsules form a polymeric outer shell over a lipophilic inner core. Drug release rate is slower than nanospheres due to the polymeric membrane but the drug carrying capacity is higher in the core.

Drug molecules may be carried inside polymeric matrix or adsorbed to the NP surface. These systems may also be prepared as polymerdrug or polymer-protein conjugates obtained by chemically linking the polymer and the active molecule. This binding can take place directly if there is sufficient interaction between the drug and the polymer, but it is usually done using a variety of binding molecules.

It is expected that at the targeted site, the molecules that bind polymer and drug are broken down and the drug is released, which leads to the desired effect. This degredation may occur enzymatically or via hydrolysis in the biological medium (49). The prepared NPs can also release the drug in the presence of various stimuli such as heat, $\mathrm{pH}$ or light, depending on the nature of the polymer used.

Advantages and disadvantages of polymeric drug delivery systems depend on physiochemical properties of different polymers used and the production techniques (50).

One of the best examples in this group is Abraxane. The hydrophobic drug paclitaxel is delivered by bounding to Albumin. Biodegradability, lack of toxicity and immunogenicity and good facilitated uptake in tumor and inflamed tissue are among the properties that make Albumin a good carrier (51). The bioavailability of paclitaxel is highly boosted in Abraxane that resulted in better intra-tumor concentrations assisted by albumin-receptor (gp60) mediated endothelial transcytosis (52-54). It undergoes biphasic elimination (twocompartment model of disposition) with a terminal half- life of 27 hours (5.8 hours for paclitaxel). The clearance is $43 \%$ slower $(15 \mathrm{~L} / \mathrm{h} / \mathrm{m} 2)$ and the mean volume of distribution is $632 \mathrm{~L} / \mathrm{m} 2$ (indicating extensive extravascular distribution). The drug exposure (AUC) was proportional to the dose in the range of $80-375 \mathrm{mg} / \mathrm{m} 2$. Reconstitution potential of Abraxabne in saline is increased to 2$10 \mathrm{mg} / \mathrm{ml}$ from that of $0.3-1.2 \mathrm{mg} / \mathrm{ml}$ in paclitaxel. 
The terminal half- life of 5.8 hours in paclitaxel was also increased to 27 hours in Abraxabne. The clearance was $43 \%$ slower $(15 \mathrm{~L} / \mathrm{h} / \mathrm{m} 2)$ and extravascular distribution was increased (mean volume of distribution is $632 \mathrm{~L} / \mathrm{m} 2$ ). The drug exposure (AUC) was proportional to the dose in the range of $80-375 \mathrm{mg} / \mathrm{m} 2$ (55). In 2005, FDA approved Abraxane for metastatic breast cancer in the first place. Later in 2012, it was approved for advanced non-small cell lung cancer and advanced pancreatic cancer. Abraxane was also approved by EMA for metastatic pancreatic cancer in 2013.

Genexol-PM that was discussed under micelles title is a good example of polymeric micelles. CRLX101 is a drug-conjugate formulation of camptothecin and a cyclodextranPEG polymer that was studied in several clinical trials for different types of cancer (44)

Weiss et al. (56) reported the first-in-human phase 1/2a trial of CRLX101 in patients with advanced solid tumors. Active ingredient of CRLX101 is Camptothecin (CPT) that works via interaction with DNA. However, this interaction is non-covalent and reverses within minutes of drug removal. Furthermore, CPT is known to cause considerable toxicity, including diarrhoea and myelosuppression. In CRLX101, cyclodextrincontaining polymer (CDP) is conjugated to CPT. This conjugation increases the solubility by three orders and decreases the inactivation rate. Both in preclinical studies and human models, renal clearance was decreased but plasma half-life was increased in conjugated form of CPT (57-60). With CRLX101 CPT, accumulation in tumor site was increased (61) and prolonged release of CPT enhanced the antitumor activity. In both pharmacokinetic and excretion studies, polymerconjugated form showed promising results in comparison with unconjugated form. Extended slowly release of drug from polymer lead to sustained Cmax. AUCall data showed that conjugation increased CPT exposure by about eleven fold. Majority of excreted drug was in conjugated form (16.2\% of the total CRLX101 vs $4.4 \%$ unconjugated). Table 4 gives more examples of this group of nanoparticles.

\section{Nanocrystals}

Drug nanocrystals are crystal structures with particle sizes in the nanometer region. Nanocrystals consist of $100 \%$ drug molecules and since they are in nano size, they do not need any careers. The surface area of nanocrystals is more than that of the micron-sized particles. This large surface area causes an increase in the dissolution rate of particles and hence an increase in bio- availability. Dispersion of nanocrystals in an aqueous medium is called nano-suspension. Generally, stabilization of the dispersed particles must be ensured, therefore various surfactants or different polymers are added to the dispersion medium.

As they can be used orally in tablets and capsules, nanocrystals may also be administered parenterally due to their small particle size (62). As a nanocrystal, the active ingredient given to the body needs to dissolve in the target tissue and turn into a molecular state in order to be effective. Also, consideration should be given to the toxicity of nanoparticles going to the regions other than the target tissue.

Although there are several FDA approved nanocrystals for different diseases, there is not any anticancer among them yet. However, some cases have gone through clinical trials (63).

Panzem $^{\circledR} \quad$ (Nanocrystalline 2methoxyestradiol) is an example that was used for different types of cancer. Harrison et al. (64) conducted a trial to evaluate the medicine for the treatment of metastatic castrate-resistant prostate cancer. Despite promising pre-clinical results, in this study, the formulation didn't show significantly successful results. However, it is reported to show biological activity and to be well tolerated. It is concluded that this unpromising results can be due to highly aggressive nature and level of disease.

Thymectacin is another poorly soluble drug that was made bioavailable as nanocrystal under trade name of Theralux ${ }^{\circledR}$. Eradication of cancerous cells from bone marrow transplants in nonHodgkin's lymphoma was one of areas that the drug was used.

NBTXR3 is a crystalline solution of hafnium oxide nanoparticles. Tourneau et al. (65) reported diminish in tumor size when they used NBTXR3 upon exposure to radiotherapy compared to just radiotherapy.

\section{Quantum dots}

Quantum dots are semiconductor nanocrystals with 2-10 $\mathrm{nm}$ dimensions. Their optical and electrical properties are different from other nanoparticles because of their very small size. Small-sized particles $(2-3 \mathrm{~nm})$ radiate in short wavelength and appear blue-green. Larger particles $(5-6 \mathrm{~nm})$ radiate in longer wavelengths and appear orange-red. The number of electrons, structure and shape of particles can be changed in the desired format. Because of these properties, they are investigated in medicine mainly in imaging and early diagnosis. Various 
investigations on toxicity of quantum dots have been conducted but due to the diversity and unique behaviour of the materials used in their production, no definite result has been achieved (66).

Olerile et al. (67) reported co-delivery of PTX CdTe@CdS@ZnS QDs using lipid carriers. Encapsulation efficacy was reported to be $\sim 80 \%$ while drug loading and tumor growth inhibition rate were $4.68 \%$ and $77.85 \%$, respectively.

Zhao et al. (68) reported another platform for chemotherapy and fluorescence imaging. PTX was loaded to the hydrophobic inner core while coated with a hydrophilic silica shell and ZnSe:Mn@ZnS QDs. The targeting responsible part was amino groups on the surface. The system increased the solubility of PTX in a 630 order and it sustain released in $12 \mathrm{~h}$.

Cai X et al. (69) targeted overexpressed glycoprotein CD44 in cancer cells with polyethylene glycol (PEG) and hyaluronic acid functionalized $\mathrm{pH}$-responsive $\mathrm{ZnO}$ QDs loaded with Doxorubicin. The system was reported to release the drug under acidic intracellular conditions. Integration of anticancer effect of $\mathrm{Zn}^{2+}$ and DOX led to a synergistic therapy.

\section{Fullerenes}

Fullerenes are empty, spherical, elliptical or cylindrical shaped carbon-based particles. Fullerenes have different number of carbon atoms but the most well-known and first produced fullerene structure has 60 carbons. Spherical fullerenes, also called Buckyball, have a particle size of about $1 \mathrm{~nm}$ (70). Cylindrical fullerenes are called carbon nanotubes or "buckytubes" (71). Carbon nanotubes, which can be found as singlelayer or multi-layer, are among the most durable materials known. Unmodified carbon nanoparticles are insoluble in water, so surface modification is required to achieve water solubility and reduce cytotoxicity. Carbon-based nanocarriers easily penetrate into cells due to their hydrophobic nature, but they have been shown to have negative effects on the immune system (72).

Zakharian et al. (73) designed a C60-PTX to target lung cancer. Bioavailability and therapeutic efficacy of PTX was improved. Half-life of PTX in bovine serum was $80 \mathrm{~min}$ and the PTX release took place by enzymatic hydrolysis.

Another successful C60 conjugation via a carbamate linker with doxorubicin was reported by Chaudhuri et al. (74). High in vitro and in vivo activity without systemic toxicity like free DOX is reported.

\section{Metallic nanoparticles}

Metallic nanoparticles are generally colloidal drug delivery systems prepared using soil elements such as gold, platinum, silver, copper and iron oxide. Metallic nanoparticles can be prepared in different sizes and shapes, and their surfaces can easily be modified and functionalized with different molecules. Metallic nanoparticles have properties that vary according to the element used.

Silver nanoparticles have effective antimicrobial and antioxidant properties (75), while gold nanoparticles are used for imaging, early detection of tumors and also in thermal ablation therapy due to their unique optical and photothermal properties (76). Iron-containing nanoparticles are used for their magnetic properties. Externally applied magnetic field after application can ensure that the iron nanoparticles accumulate in the desired region (77).

The biggest disadvantage of metallic nanoparticles is that they are not biodegradable and have the risk of accumulation in the body. Toxic effects vary depending on the element and particle size used (3).

Aurimmune is a coated gold nanoparticle with thiolated PEG that was coupled to TNF- $\alpha$ for targeted delivery to tumor. This was the first successful attempt without dose-limiting toxicity that led to hypotension and nausea. Even when dose levels as high as $500-600 \mathrm{microgram} / \mathrm{m}^{2}$ of TNF- $\alpha$ was used, the side effect was limited to grade 2 fever (78).

Libutti et al. (79) also reported promising results of Phase I and pharmacokinetic studies of Aurimmune (CYT-6091) previously. PK analysis was performed for total rhTNF as it is not possible to assay for bound versus free rhTNF, nor is it possible to quantify the amount of gold based upon the sensitivity of available assay techniques.

AuroShell is another example that went through clinical trials. A thin layer of gold is coated on silica particles. Several studies reported successful use of AuroShell in photothermal therapy or along with radiation or standard chemotherapy (78, 80-84).

$\mathrm{Gad}$ et al. (85) evaluated the toxicity of AuroShell when intravenously delivered. Evaluation was based on internationally recognized tests in vivo and in vitro. Nanoshells were totally well tolerated and biocompatible and in none of the studied toxicity was observed.

\section{PEGylation}

One of the biggest problems faced with nanoparticles after they enter the blood circulation is their recognition as foreign materials and 
elimination by opsonization. Complement protein is an opsonin type protein and is stimulated by the entry of foreign materials into the body. As a result of this warning, the complement protein interacts with the foreign particles surface and causes the particles to be eliminated by the macrophages. If the surface of the particles is coated with a hydrophilic polymer prior to the administration, this opsonization event can be reduced or even completely prevented. One of the most suitable polymers used to coat the particle's surface is the PEG polymer, and this coating process is referred to as PEGylation; (coating nanoparticle surface with poly ethylene glycol (PEG)).

PEG chains are attached to the surface of the particle by chemical bonding or by physical interactions. PEG is a hydrophilic polymer, which causes the accumulation of a dense water layer on the surface of the nanoparticle. The thickness of this layer and PEG coverage of the surface directly affect the opsonization level of the particles.

PEG polymers that cover the entire surface of the particles in a dense manner provide good protection against opsonins as they will form a thick water layer. However, a small number of PEG chains may not be effective enough (Fig. 2) (86, 87). Nanomedicines prepared with PEGylation stay for a longer time in the circulation and are more likely to reach the desired target.
Genexol-PM that was mentioned under micelle group and also Oncaspar ${ }^{\circledR}$ that was mentioned under nanoemulsion are PEGylated.

Sylatron ${ }^{\mathrm{TM}}\left(\mathrm{PEG}_{\mathrm{INTRON}}{ }^{\circledR}\right)$ is the PEGylated version of interferon- $\alpha 2 b$ that got FDA approval to be used for adjuvant therapy in treatment of melanoma (88). The half-life was found to be $27-$ $37 \mathrm{~h}$, clearance decreased 10 fold and a minor change was observed in comparison with nonPEGylated form.

Thermodox is another formulation that went through clinical trials for treatment of hepatobiliary tumors (89) . It is a thermosensitive, PEG bounded, liposomal doxorubicin that releases the drug when exposed to high heat (44).

CALLA 01 by Calando Pharmaceuticals is transferrin conjugated cyclodextrin nanoparticle coated with PEG. It was the first formulation to go under phase I clinical trials for solid tumors (90).

Kurmi et al. (91) delivered methotrexate to lung cancer using Lactoferrin-conjugated dendrimers and compared it with the free form. pharmacokinetic and pharmacodynamic properties were also investigated. Elimination half-life of MTX-loaded plain PEGylated poly (propylene imine) (PPI) dendrimer $(10.41 \pm 2.12 \mathrm{~h}, \mathrm{p}<0.05)$ increased $(12.23 \pm 1.53 \mathrm{~h}, \mathrm{p}<0.01)$ MTX-loaded Lf-conjugated PEGylated PPI dendrimer. Overall, a prolonged systemic exposure and increased lung accumulation were achieved.
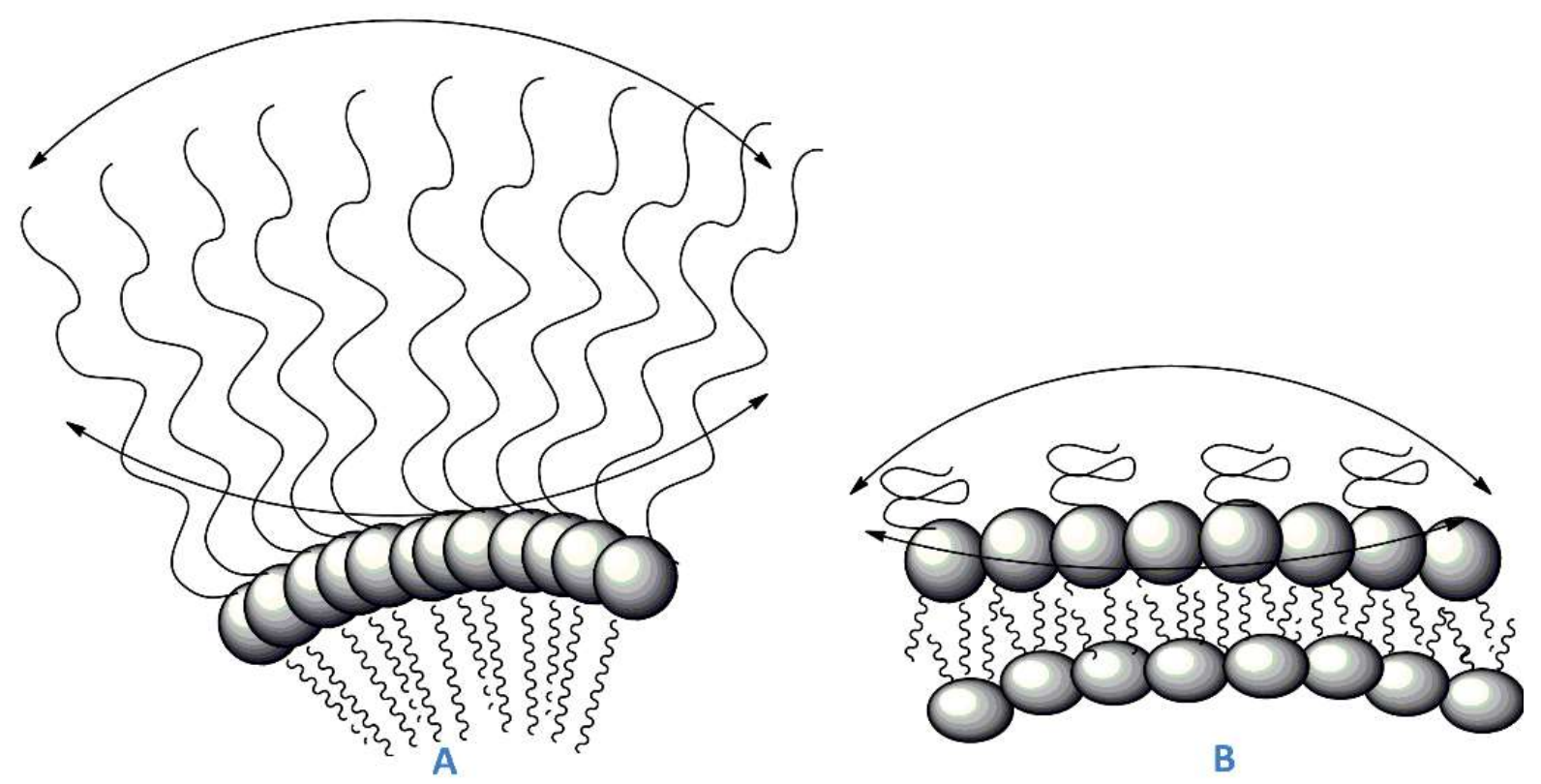

Figure 2. When the surface of the nanoparticle is coated with PEG, two situations may happen: (A), highly bent particle's surface and high PEGylation give these chains a "brush" look which ensures thickness of the stagnant water layer that covers the surface and (B), less bent particle's surface and insufficient PEGylation give these chains a "fungus" appearance, and causes the surface water layer to be thin and discontinuous, which is insufficient to protect the particle against opsonization. 
Passive targeting of nanodrugs after intravenous administration

As free drug molecules enter the bloodstream through injection or oral route and since they are very small in size, they pass the spaces between the endothelial cells (3-4 nm) of the blood vessels and distribute throughout the body. However, since nanodrugs are larger in size than the spaces between blood vessels, they remain in the circulation for a longer time, especially when their surface is coated with PEG. As a result, the probability of drugs in nano-carriers reaching the diseased area is much higher than free drugs.

In cancer and inflammatory tissues, blood vessels are highly permeable and the gaps among them are larger than $100 \mathrm{~nm}$ and sometimes even $800 \mathrm{~nm}$ in size. Nanoparticles that reach the affected region pass to the diseased tissue through the gaps in these vessels and stay there (Enhanced Permeability and Retention (EPR)). Drug molecules are then released from the carriers and exert the desired pharmacological effects (Fig. 3). This mechanism is referred to as delivering the drug to the target by passive mechanism (28). This method is one of the most successful instances of application of nano-technology in medicine.

Surface of nanoparticles may also be functionalized with different targeting moieties that interact with the specific markers in the region (92) .This active targeting results in increased drug accumulation in the target cells. Active targeting mechanism and other targeting methods are outside the scope of this review, but the reader may refer to other publications for more information (93). The targeted nanoparticles may not only show a higher effect due to increased drug concentration and specificity at the diseased tissues, but also reduce or even eliminate toxicity and side effects of the drug. This is due to the facts that drug in nanocarriers cannot extravasate the healthy vessels to permeate into healthy tissues, and also does not interact with blood cells in the circulation.

\section{CONTRIBUTION OF NANOMEDICINES TO SOCIAL WELFARE, HEALTH AND ECONOMY}

The contributions of nanotechnology to the medical field are important for the society from many perspectives. This technology provides new products, from visualization to diagnosis and every area of treatment, and contributes to the health care and economics of the society in many ways as summarized in Table 2.

Table 3 and 4 are representing the majority of examples of nanoformulations in cancer therapy. The active ingredients, company/sponsor, indications, status, application and trial numbers linked to source of information in FDA, EMA or other related recourses for further information are given.

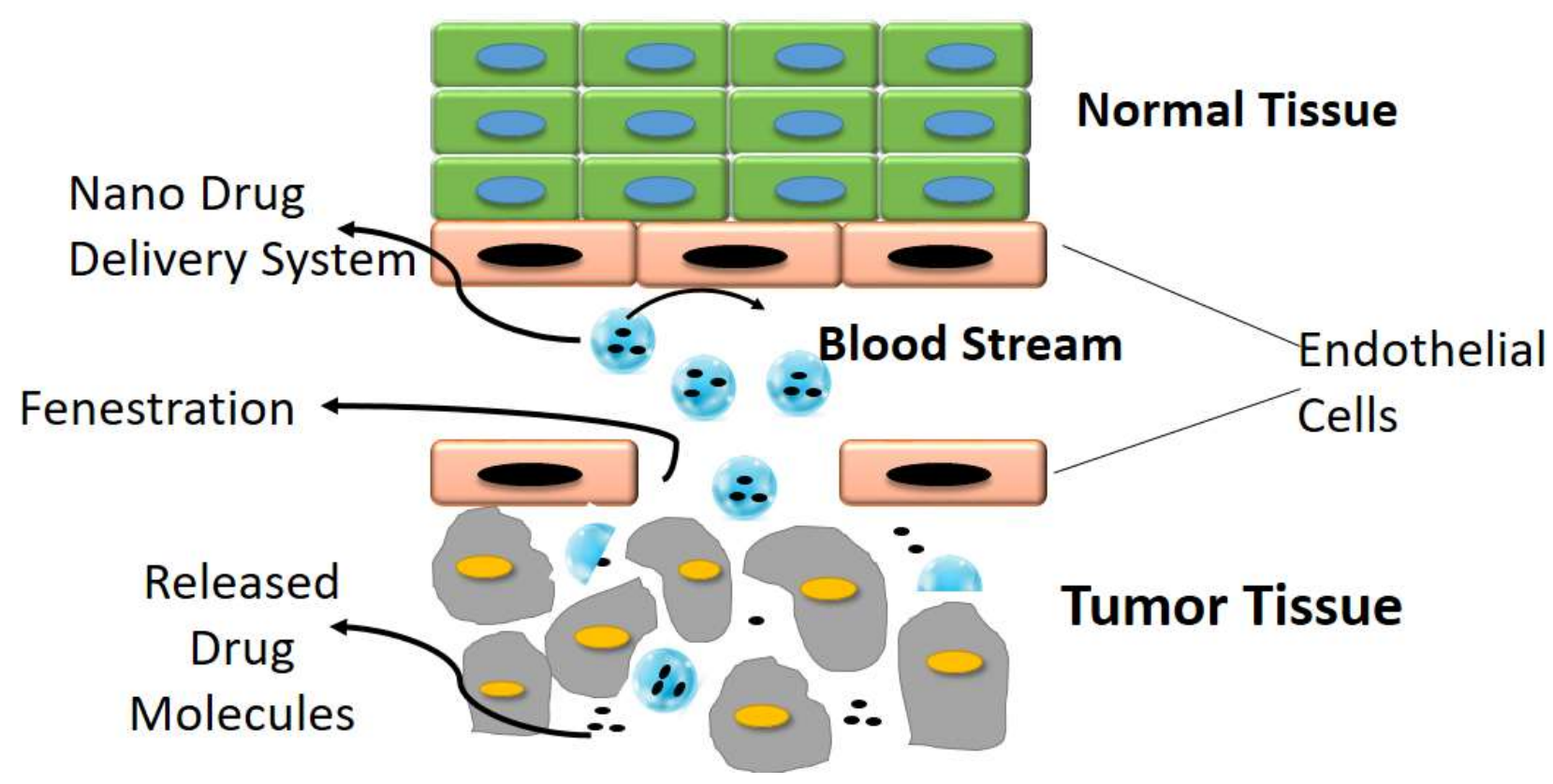

Figure 3. Enhanced Permeability and Retention (EPR) effect. 
Table 2. Contribution of nanotechnology to the health care and economy from different perspectives (94)

\section{Industrial Perspective}

1. Upgrading the added value of high cost biopharmaceuticals

- Similar effect with lower dose, improved efficacy with the same dose, controlled drug release and improved pharmacokinetic profile can be achieved.

2. Reformulation of existing drugs

- Increase of drug half-life, reusing the drugs that have serious side effects and repositioning may be possible

\section{Health Care System Perspective}

1. Allowing rational drug use

2. Reduction of health expenditures in general

- Increasing the drug efficacy, prolonging the half-life, reduction of personal health care costs and the effective treatment of common, expensive diseases

3. Improving the quality of health care services

\section{Clinical Perspective}

1. Possibility of more effective and less toxic interventions

2. Patient-friendly approaches

3. Personalized treatments

4. Possibility of using targeted medicines

5. Accelerating the treatment process

6. Achieving better results in patients' complaints and physical appearance

7. Improvement of medical and pharmaceutical care

\section{Patient Perspective}

1. Decreasing dose frequency and prolongation of dose intervals

2. Ability to be applied by minimally invasive methods

3. Receiving maximum result from treatment

4. Reducing side effects

5. Increasing life quality of the patient

Table 3. Examples of approved and in clinical trial Liposomal formulations.

\begin{tabular}{|c|c|c|c|c|c|}
\hline Product name & $\begin{array}{l}\text { Active } \\
\text { ingredient }\end{array}$ & $\begin{array}{l}\text { Company/ } \\
\text { Sponsor }\end{array}$ & Indication & Status & Source \\
\hline DaunoXome & $\begin{array}{l}\text { Daunorubici } \\
\mathrm{n}\end{array}$ & Galen & $\begin{array}{l}\text { AIDS-related } \\
\text { Kaposi's sarcoma, } \\
\text { metastatic ovarian } \\
\text { cancer, metastatic } \\
\text { breast cancer, } \\
\text { multiple myeloma }\end{array}$ & $\begin{array}{l}\text { FDA Approved } \\
1996\end{array}$ & $\begin{array}{l}\text { New Drug } \\
\text { Application } \\
\text { (NDA): } 050704\end{array}$ \\
\hline Doxil/Caelyx & $\begin{array}{l}\text { Doxorubicin } \\
\text { Hcl }\end{array}$ & Janssen & $\begin{array}{l}\text { AIDS-related } \\
\text { Kaposi's sarcoma, } \\
\text { Acute myeloid } \\
\text { leukemia, ovarian } \\
\text { cancer }\end{array}$ & $\begin{array}{l}\text { FDA Approved } \\
1995\end{array}$ & $\begin{array}{l}\text { New Drug } \\
\text { Application } \\
\text { (NDA): } 050718 \\
\end{array}$ \\
\hline DepoCyte & Cytarabine & $\begin{array}{l}\text { Depotech } \\
\text { Corporation } \\
\text { Sigma-Tau }\end{array}$ & $\begin{array}{l}\text { Lymphomas or } \\
\text { leukemia with } \\
\text { meningeal spread add } \\
\text { Neoplastic meningitis }\end{array}$ & $\begin{array}{l}\text { FDA } \\
\text { accelerated appr } \\
\text { oval in } 1999 \\
\text { and } \\
\text { full approval in } \\
2007\end{array}$ & $\begin{array}{l}\text { Application } \\
\text { No.: 21-041 }\end{array}$ \\
\hline $\begin{array}{l}\text { Onivyde (MM- } \\
\text { 398) }\end{array}$ & Irinotecan & $\begin{array}{l}\text { Merrimack } \\
\text { Pharmaceuti } \\
\text { cal, Inc. }\end{array}$ & Pancreatic cancer & $\begin{array}{l}\text { FDA Approved } \\
2015\end{array}$ & $\begin{array}{l}\text { Application } \\
\text { No.: } 207793\end{array}$ \\
\hline $\begin{array}{l}\text { Marqibo } \\
\text { (vinCRIStine } \\
\text { sulfate } \\
\text { LIPOSOME } \\
\text { injection) }\end{array}$ & Vincristine & $\begin{array}{l}\text { Talon } \\
\text { Therapeutics } \\
\text {, Inc. }\end{array}$ & $\begin{array}{l}\text { Acute lymphoid } \\
\text { leukemia }\end{array}$ & $\begin{array}{l}\text { FDA Approved } \\
2012\end{array}$ & $\frac{\text { Application }}{\text { No.: 202497 }}$ \\
\hline $\begin{array}{l}V_{y x e o s}{ }^{T M} / d a u \\
\text { norubicin }\end{array}$ & $\begin{array}{l}\text { Daunorubici } \\
\mathrm{n} \text { and } \\
\text { Cytarabine }\end{array}$ & $\begin{array}{l}\text { Jazz } \\
\text { Pharmaceuti } \\
\text { cals plc }\end{array}$ & $\begin{array}{l}\text { Acute Myeloid } \\
\text { Leukemia }\end{array}$ & $\begin{array}{l}\text { FDA Approved } \\
2017\end{array}$ & $\frac{\text { Application No.: }}{\underline{209401}}$ \\
\hline
\end{tabular}


Table 3. Continued...

\begin{tabular}{|c|c|c|c|c|c|}
\hline MEPACT & $\begin{array}{l}\text { Mifamurtide } \\
\text { acting }\end{array}$ & $\begin{array}{l}\text { IDM } \\
\text { Pharma }\end{array}$ & Osteosarcoma & $\begin{array}{l}\text { EMA Approved } \\
2013\end{array}$ & $\underline{\mathrm{EMEA} / \mathrm{H} / \mathrm{C} / 000802}$ \\
\hline Myocet & $\begin{array}{l}\text { Doxorubicin } \\
\text { liposome }\end{array}$ & Teva UK & Breast & $\begin{array}{l}\text { EMA Approved } \\
(2000)\end{array}$ & EMEA/H/C/000297 \\
\hline CPX-1 & Irinotecan & $\begin{array}{l}\text { Jazz } \\
\text { Pharmaceuti } \\
\text { cals }\end{array}$ & $\begin{array}{l}\text { Colorectal cancer or } \\
\text { colon cancer }\end{array}$ & Phase II & NCT00361842 \\
\hline $\begin{array}{l}\text { Liposome } \\
\text { Encapsulated } \\
\text { SN38 (LE- } \\
\text { SN38) }\end{array}$ & Sn-38 & $\begin{array}{l}\text { Insys } \\
\text { therapeutics } \\
\text { inc ph1 (cli } \\
\text { trials) }\end{array}$ & Neoplasms & Phase II & $\underline{\mathrm{NCT} 00046540}$ \\
\hline Lipoplatin & Cisplatin & $\begin{array}{l}\text { Centre } \\
\text { Hospitalier } \\
\text { Universitair } \\
\text { e Vaudois }\end{array}$ & $\begin{array}{l}\text { Non small cell lung } \\
\text { cancer (NSCLC), } \\
\text { breast cancer, gastric } \\
\text { cancer }\end{array}$ & Phase III & NCT02702700 \\
\hline $\begin{array}{l}\text { Cisplatin } \\
\text { liposomal } \\
\text { (SLIT } \\
\text { Cisplatin) }\end{array}$ & Cisplatin & $\begin{array}{l}\text { Insmed } \\
\text { Incorporated }\end{array}$ & $\begin{array}{l}\text { Osteosarcoma } \\
\text { Metastatic }\end{array}$ & $\begin{array}{l}\text { Phase I } \\
\text { Phase II }\end{array}$ & NCT00102531 \\
\hline $\begin{array}{l}\text { Liposomal- } \\
\text { Cisplatin Anal } \\
\text { ogue (L- } \\
\text { NDDP) }\end{array}$ & Cisplatin & $\begin{array}{l}\text { NYU } \\
\text { Langone } \\
\text { Health }\end{array}$ & $\begin{array}{l}\text { Malignant } \\
\text { Mesothelioma }\end{array}$ & Phase II & NCT00004033 \\
\hline
\end{tabular}

\begin{tabular}{|c|c|c|c|c|c|}
\hline Aroplatin & $\begin{array}{l}\text { NDDP (bis- } \\
\text { neodecanoat } \\
\text { o- trans- } \\
\text { R,R-1,2- } \\
\text { diaminocycl } \\
\text { ohexane } \\
\text { plati- } \\
\text { num(II)) }\end{array}$ & $\begin{array}{l}\text { Aronex } \\
\text { Pharmaceuti } \\
\text { cals }\end{array}$ & $\begin{array}{l}\text { Refractory colorectal } \\
\text { can- cer, malignant } \\
\text { pleural mesothelioma }\end{array}$ & Phase II & NCT00081549 \\
\hline $\begin{array}{l}\text { liposomal } \\
\text { oxaliplatin } \\
\text { (MBP-426) }\end{array}$ & Mbp-426 & $\begin{array}{l}\text { Mebiopharm } \\
\text { co., ltd }\end{array}$ & $\begin{array}{l}\text { Advanced gastro- } \\
\text { intestinal cancer }\end{array}$ & Phase I & NCT00355888 \\
\hline $\begin{array}{l}\text { Liposomal } \\
\text { Oxaliplatin/Fo } \\
\text { linic Acid/5- } \\
\text { Fluorouracil }\end{array}$ & $\begin{array}{l}\text { Mbp- } \\
426 / \text { leucovo } \\
\mathrm{rin} / 5-\mathrm{fu}\end{array}$ & $\begin{array}{l}\text { Mebiopharm } \\
\text { co., ltd }\end{array}$ & $\begin{array}{l}\text { Gastric } \\
\text { adenocarcinomagastr } \\
\text { oesophageal junction } \\
\text { adenocarcinomaesop } \\
\text { hageal } \\
\text { adenocarcinoma }\end{array}$ & Phase II & NCT00964080 \\
\hline $\begin{array}{l}\text { Anti-EGFR } \\
\text { ILs-DOX }\end{array}$ & $\begin{array}{l}\text { C225-ils- } \\
\text { dox }\end{array}$ & $\begin{array}{l}\text { University } \\
\text { Hospital, } \\
\text { Basel, } \\
\text { Switzerland }\end{array}$ & Glioblastoma & Phase I & NCT03603379 \\
\hline 2B3-101 & Dox & $\begin{array}{l}\text { Bbb- } \\
\text { therapeutics } \\
\text { b.v. }\end{array}$ & Glioma & Phase I, II & NCT01386580 \\
\hline
\end{tabular}


Table 3. Continued...

\begin{tabular}{|c|c|c|c|c|c|}
\hline MM-302 & Dox & $\begin{array}{l}\text { Merrimack } \\
\text { pharmaceuti } \\
\text { cals }\end{array}$ & $\begin{array}{l}\text { Advanced breast } \\
\text { cancer }\end{array}$ & Phase I & NCT01304797 \\
\hline $\begin{array}{l}\text { ThermoDox } \\
\text { Liposomal } \\
\text { Doxorubicin }\end{array}$ & Dox & $\begin{array}{l}\text { Celsion } \\
\text { company }\end{array}$ & $\begin{array}{l}\text { Primary } \\
\text { hepatocellular } \\
\text { carcinoma refractory } \\
\text { chest wall breast } \\
\text { cancer colorectal } \\
\text { liver metastases }\end{array}$ & Phase III & $\begin{array}{l}\text { NCT00617981 } \\
\text { NCT02112656* } \\
\end{array}$ \\
\hline $\begin{array}{l}\text { Liposomal } \\
\text { annamycin }\end{array}$ & Annamycin & $\begin{array}{l}\text { NYU } \\
\text { Langone } \\
\text { Health }\end{array}$ & $\begin{array}{l}\text { DOX-resistant breast } \\
\text { cancer }\end{array}$ & $\begin{array}{l}\text { Phase I, } \\
\text { Phase II }\end{array}$ & NCT00012129 \\
\hline LEM & $\begin{array}{l}\text { Mitoxantron } \\
\text { e }\end{array}$ & $\begin{array}{l}\text { INSYS } \\
\text { Therapeutics } \\
\text { Inc }\end{array}$ & Tumors & Phase I & NCT00024492 \\
\hline SPI-77 & Cisplatin & $\begin{array}{l}\text { NYU } \\
\text { Langone } \\
\text { Health } \\
\text { /National } \\
\text { Cancer } \\
\text { Institute } \\
\text { (NCI) }\end{array}$ & Ovarian cancer & Phase II & NCT00004083 \\
\hline LiPlaCis & Cisplatin & $\begin{array}{l}\text { Oncology } \\
\text { Venture }\end{array}$ & $\begin{array}{l}\text { Phase 1: Advanced or } \\
\text { Refractory Solid } \\
\text { tumoursphase } 2 \text { Part: } \\
\text { Metastatic Breast } \\
\text { Cancer, Prostate } \\
\text { Cancer and Skin } \\
\text { Cancer }\end{array}$ & $\begin{array}{l}\text { Phase I, Phase } \\
\text { II }\end{array}$ & NCT01861496 \\
\hline $\begin{array}{l}\text { Nanoliposomal } \\
\text { CPT-11 }\end{array}$ & Irinotecan & $\begin{array}{l}\text { University } \\
\text { of } \\
\text { California, } \\
\text { San } \\
\text { Francisco }\end{array}$ & $\begin{array}{l}\text { Glioblastomagliosarc } \\
\text { omaanaplastic } \\
\text { astrocytomaanaplasti } \\
\text { c Oligodendroglioma }\end{array}$ & Phase I & NCT00734682 \\
\hline L9NC & $\begin{array}{l}\text { 9-nitro-20 } \\
\text { (S)- } \\
\text { camptotheci } \\
n\end{array}$ & $\begin{array}{l}\text { University } \\
\text { of New } \\
\text { Mexico }\end{array}$ & $\begin{array}{l}\text { Corpus Uteri } \\
\text { Lung Cancer }\end{array}$ & Not applicable & NCT00277082 \\
\hline IHL-305 & $\begin{array}{l}\text { Irinotecan } \\
\text { phase }\end{array}$ & $\begin{array}{l}\text { Yakult } \\
\text { honsha co., } \\
\text { ltd }\end{array}$ & $\begin{array}{l}\text { Advanced solid } \\
\text { tumor }\end{array}$ & Phase I & NCT00364143 \\
\hline PEP02 & Irinotecan & $\begin{array}{l}\text { Pharmaengi } \\
\text { ne }\end{array}$ & $\begin{array}{l}\text { Stomach } \\
\text { neoplasmsesophageal } \\
\text { Neoplasms }\end{array}$ & Phase II & NCT00813072 \\
\hline TLI & Topotecan & $\begin{array}{l}\text { Spectrum } \\
\text { Pharmaceuti } \\
\text { cals, Inc }\end{array}$ & $\begin{array}{l}\text { Solid tumor, ovarian } \\
\text { cancer, small cell } \\
\text { lung cancer }\end{array}$ & Phase I & NCT00765973 \\
\hline PNU-93914 & Ptx & $\begin{array}{l}\text { Memorial } \\
\text { sloan } \\
\text { kettering } \\
\text { cancer } \\
\text { center }\end{array}$ & Esophageal cancer & Phase II & NCT00016900 \\
\hline
\end{tabular}


Table 3. Continued...

\begin{tabular}{|c|c|c|c|c|c|}
\hline LEP-ETU & Ptx & $\begin{array}{l}\text { Insys } \\
\text { therapeutics } \\
\text { inc }\end{array}$ & Neoplasms & Phase I & $\underline{\text { NCT00100139 }}$ \\
\hline $\begin{array}{l}\text { VLI } \\
\text { (vinorelbine } \\
\text { liposomes) }\end{array}$ & Vinorelbine & $\begin{array}{l}\text { Spectrum } \\
\text { Pharmaceuti } \\
\text { cals, Inc }\end{array}$ & $\begin{array}{l}\text { Tumorshodgkins } \\
\text { diseasenon-Hodgkins } \\
\text { Lymphoma }\end{array}$ & Phase I & NCT00364676 \\
\hline CPX-351 & $\begin{array}{l}\text { Combinatio } \\
\mathrm{n} \text { of } \\
\text { cytarabine } \\
\text { and } \\
\text { daunorubici } \\
\mathrm{n}\end{array}$ & $\begin{array}{l}\text { Jazz } \\
\text { Pharmaceuti } \\
\text { cals }\end{array}$ & $\begin{array}{l}\text { Acute myeloid } \\
\text { leukemia }\end{array}$ & Phase I & $\underline{\mathrm{NCT} 04038437}$ \\
\hline SGT-53 & P53 gene & $\begin{array}{l}\text { Synergene } \\
\text { Therapeutics } \\
\text {, Inc. }\end{array}$ & Solid tumor & Phase I & NCT00470613 \\
\hline $\begin{array}{l}\text { LErafAON- } \\
\text { ETU }\end{array}$ & $\begin{array}{l}\text { Antisense } \\
\text { oligonucleot } \\
\text { ide }\end{array}$ & $\begin{array}{l}\text { Insys } \\
\text { therapeutics } \\
\text { inc }\end{array}$ & Neoplasm & Phase I & NCT00100672 \\
\hline NX 211 & Lurtotecan & $\begin{array}{l}\text { Astellas } \\
\text { Pharma Inc } \\
\text { /OSI } \\
\text { Pharmaceuti } \\
\text { cals }\end{array}$ & Ovarian cancer & Phase II & $\underline{\mathrm{NCT} 00046800}$ \\
\hline LE-DT & Docetaxel & $\begin{array}{l}\text { INSYS } \\
\text { Therapeutics } \\
\text { Inc }\end{array}$ & Pancreatic cancer, & Phase II & NCT01186731 \\
\hline L-BLP25 & Tecemotide & $\begin{array}{l}\text { Merck kgaa, } \\
\text { Darmstadt, } \\
\text { Germany }\end{array}$ & $\begin{array}{l}\text { Carcinoma, Non- } \\
\text { Small-Cell Lung } \\
\text { Neoplasms }\end{array}$ & Phase II & NCT00157196 \\
\hline $\begin{array}{l}\text { Lipovaxin- } \\
\text { MM }\end{array}$ & $\begin{array}{l}\text { 3- } \\
\text { nitrlotriaceti } \\
\text { c acid linked } \\
\text { to } \\
\text { ditetradecyla } \\
\text { mine lipid } \\
\text { liposome } \\
\text { with } \\
\text { histidine } \\
\text { tagged } \\
\text { targeting } \\
\text { ligands }\end{array}$ & $\begin{array}{l}\text { Lipotek pty } \\
\text { ltd/ } \\
\text { Royal } \\
\text { adelaide } \\
\text { hospital/ } \\
\text { Trident } \\
\text { clinical } \\
\text { research pty } \\
\text { ltd }\end{array}$ & Melanoma & Phase I & NCT01052142 \\
\hline $\begin{array}{l}\text { BP1001 L- } \\
\text { Grb-2 } \\
\text { Antisense } \\
\text { Oligonucleotid } \\
\text { e }\end{array}$ & $\begin{array}{l}\text { Grb-2 } \\
\text { (Growth } \\
\text { factor } \\
\text { receptor- } \\
\text { bound } \\
\text { protein 2) }\end{array}$ & $\begin{array}{l}\text { Bio-Path } \\
\text { Holdings, } \\
\text { Inc. }\end{array}$ & $\begin{array}{l}\text { Recurrent Adult } \\
\text { Acute Myeloid } \\
\text { Leukemia } \\
\text { Acute Lymphoblastic } \\
\text { Leukemia } \\
\text { Myelodysplastic } \\
\text { Syndrome } \\
\text { Ph1 Positive CML }\end{array}$ & Phase I & NCT01159028 \\
\hline
\end{tabular}


Table 3. Continued...

\begin{tabular}{|c|c|c|c|c|c|}
\hline $\begin{array}{l}\text { SPI-077 } \\
\text { (Liposomal } \\
\text { Cisplatin) }\end{array}$ & Cisplatin & $\begin{array}{l}\text { NYU } \\
\text { Langone } \\
\text { Health/ } \\
\text { National } \\
\text { Cancer } \\
\text { Institute } \\
\text { (NCI) }\end{array}$ & Ovarian Cancer & Phase II & NCT00004083 \\
\hline OSI-7904L & $\begin{array}{l}\text { Thymidylate } \\
\text { synthase in- } \\
\text { hibitor }\end{array}$ & $\begin{array}{l}\text { OSI } \\
\text { Pharmaceuti } \\
\text { cals }\end{array}$ & $\begin{array}{l}\text { Locally Recurrent or } \\
\text { Metastatic Cancer of } \\
\text { the Head and Neck } \\
\text { (Must Have Failed } \\
\text { First-Line Therapy) }\end{array}$ & Phase II & NCT00116909 \\
\hline OSI-211 & Lurtotecan & $\begin{array}{l}\text { Astellas } \\
\text { Pharma Inc/ } \\
\text { OSI } \\
\text { Pharmaceuti } \\
\text { cals }\end{array}$ & $\begin{array}{l}\text { SCLC } \\
\text { Carcinoma, Small } \\
\text { Cell }\end{array}$ & Phase II & NCT00046787 \\
\hline Rexin-G & $\begin{array}{l}\text { Cyclin G1 } \\
\text { gene }\end{array}$ & $\begin{array}{l}\text { Epeius } \\
\text { Biotechnolo } \\
\text { gies }\end{array}$ & $\begin{array}{l}\text { All solid tumors, } \\
\text { osteosarcoma and } \\
\text { soft tissue sarcoma, } \\
\text { Breast cancer }\end{array}$ & $\begin{array}{l}\text { Approved in } \\
\text { Philippines } \\
\text { 2007/ Phase I, } \\
\text { Phase II }\end{array}$ & NCT00505271* \\
\hline LEP-ETU & Paclitaxel & Insys & Breast cancer & Phase II & NCT01190982 \\
\hline EndoTAG-1 & Paclitaxel & $\begin{array}{l}\text { Jules Bordet } \\
\text { Institute }\end{array}$ & Breast cancer & Phase II & $\underline{\text { NCT01537536 }}$ \\
\hline $\begin{array}{l}\text { Atragen } \\
\text { (tretinoin } \\
\text { liposome) }\end{array}$ & Tretinoin & $\begin{array}{l}\text { Weill } \\
\text { Medical } \\
\text { College of } \\
\text { Cornell } \\
\text { University } \\
\end{array}$ & Kidney Cancer & Phase II & NCT00003656 \\
\hline NKTR -102 & $\begin{array}{l}\text { Irinotecan, } \\
\text { pegylated } \\
\text { liposome }\end{array}$ & $\begin{array}{l}\text { Nektar } \\
\text { Therapeutics }\end{array}$ & $\begin{array}{l}\text { Metastatic } \\
\text { Solid Tumors/ } \\
\text { Breast /colorectal/ } \\
\text { ovarian cancer }\end{array}$ & Phase III & $\begin{array}{l}\text { NCT01492101 } \\
\text { NCT02915744 * }\end{array}$ \\
\hline
\end{tabular}

Table 4. Examples of approved and in clinical trial nanoformulations.

\begin{tabular}{|c|c|c|c|c|c|c|}
\hline $\begin{array}{l}\text { Nanomedicin } \\
\text { e type }\end{array}$ & $\begin{array}{l}\text { Product } \\
\text { name }\end{array}$ & $\begin{array}{l}\text { Active } \\
\text { ingredient }\end{array}$ & $\begin{array}{l}\text { Company/Spon } \\
\text { sor }\end{array}$ & Indication & Status & Source \\
\hline \multirow[t]{3}{*}{$\begin{array}{l}\text { Nanoemulsio } \\
\text { ns }\end{array}$} & Oncaspar $^{\circledR}$ & $\begin{array}{l}\text { Pegaspargase } \\
\text { (mpeg- } \\
\text { asparaginase) }\end{array}$ & $\begin{array}{l}\text { Sigma-tau } \\
\text { Arzneimit- tel } \\
\text { gmbh } \\
\text { Germany }\end{array}$ & $\begin{array}{l}\text { Acute } \\
\text { lymphocyti } \\
\text { c leukemia }\end{array}$ & $\begin{array}{l}\text { EMA } \\
\text { Approved } \\
2016\end{array}$ & $\begin{array}{l}\text { EMEA/H/C/0037 } \\
\underline{89}\end{array}$ \\
\hline & Zevalin $^{\circledR}$ & $\begin{array}{l}90 Y- \\
\text { ibritumomab } \\
\text { tiuxetan }\end{array}$ & Bayer Pharma & Lymphoma & $\begin{array}{l}\text { FDA } \\
\text { Approved } \\
2002\end{array}$ & $\begin{array}{l}\text { Application } \\
\text { No.: } 125019 \\
\end{array}$ \\
\hline & Zevalin $^{\circledR}$ & $\begin{array}{l}\text { Ibritumomab } \\
\text { tiuxetan }\end{array}$ & $\begin{array}{l}\text { Spectrum } \\
\text { Pharmaceutica } \\
\text { ls B.V. }\end{array}$ & $\begin{array}{l}\text { Lymphoma, } \\
\text { Follicular }\end{array}$ & $\begin{array}{l}\text { EMA } \\
\text { Approved } \\
2004\end{array}$ & $\begin{array}{l}\text { EMEA/H/C/0005 } \\
\underline{47}\end{array}$ \\
\hline
\end{tabular}


Table 4. Continued...

\begin{tabular}{|c|c|c|c|c|c|c|}
\hline \multirow[t]{2}{*}{ Metallic NPs } & $\begin{array}{l}\text { Aurimmune } \\
\text { (CYT-6091) }\end{array}$ & $\begin{array}{l}\text { TNF- } \alpha \text { bound to } \\
\text { colloidal Gold } \\
\text { nanoparticles }\end{array}$ & $\begin{array}{l}\text { National } \\
\text { Institutes of } \\
\text { Health } \\
\text { Clinical } \\
\text { Center (CC) }\end{array}$ & $\begin{array}{l}\text { Adrenocorti } \\
\text { cal } \\
\text { Carcinoma, } \\
\text { Breast, } \\
\text { Colorectal, } \\
\text { Gastrointest } \\
\text { inal, } \\
\text { Kidney, } \\
\text { Liver, } \\
\text { Ovarian and } \\
\text { Pancreatic } \\
\text { Cancers } \\
\text { Sarcoma } \\
\text { and } \\
\text { Melanoma }\end{array}$ & $\begin{array}{l}\text { Early } \\
\text { Phase I }\end{array}$ & NCT00436410 \\
\hline & $\begin{array}{l}\text { Aurimmune } \\
\text { (CYT-6091) }\end{array}$ & $\begin{array}{l}\text { TNF-Bound } \\
\text { Colloidal Gold }\end{array}$ & $\begin{array}{l}\text { National } \\
\text { Institutes of } \\
\text { Health } \\
\text { Clinical } \\
\text { Center (CC) }\end{array}$ & $\begin{array}{l}\text { Unspecified } \\
\text { Adult Solid } \\
\text { Tumor }\end{array}$ & Phase I & NCT00356980 \\
\hline \multirow[t]{5}{*}{$\begin{array}{l}\text { Polymeric } \\
\text { NPs }\end{array}$} & Adagen & $\begin{array}{l}\text { Pegademase } \\
\text { bovine }\end{array}$ & $\begin{array}{l}\text { Leadiant } \\
\text { Biosciences }\end{array}$ & SCID & $\begin{array}{l}\text { FDA } \\
\text { Approved }\end{array}$ & $\begin{array}{l}\text { New Drug } \\
\text { Application } \\
\text { (NDA): } 019818 \\
\end{array}$ \\
\hline & Eligard & $\begin{array}{l}\text { Leuprolide } \\
\text { acetate and } \\
\text { polymer }\end{array}$ & $\begin{array}{l}\text { Atrix } \\
\text { Laboratories }\end{array}$ & $\begin{array}{l}\text { Prostate } \\
\text { cancer }\end{array}$ & $\begin{array}{l}\text { FDA } \\
\text { Approved } \\
2004\end{array}$ & $\frac{\text { Application }}{\text { No.: } 021731}$ \\
\hline & Eligard & $\begin{array}{l}\text { Leuprolide } \\
\text { acetate }\end{array}$ & Tolmar & $\begin{array}{l}\text { Advanced } \\
\text { prostate } \\
\text { cancer }\end{array}$ & $\begin{array}{l}\text { Fda } \\
\text { approved } \\
2016\end{array}$ & NDA 21343/S33 \\
\hline & Oncaspar & Pegaspargase & Baxalta U.S. & ALL & $\begin{array}{l}\text { FDA } \\
\text { approved } \\
1994\end{array}$ & $\frac{\text { BLA 103411/S- }}{\underline{5196}}$ \\
\hline & Oncaspar & Pegaspargase & $\begin{array}{l}\text { Les } \\
\text { Laboratoires } \\
\text { Servier }\end{array}$ & $\begin{array}{l}\text { Precursor } \\
\text { Cell } \\
\text { Lymphobla } \\
\text { stic } \\
\text { Leukemia- } \\
\text { Lymphoma }\end{array}$ & $\begin{array}{l}\text { Approved } \\
\text { EMA } \\
2016\end{array}$ & $\frac{\mathrm{EMEA} / \mathrm{H} / \mathrm{C} / 0037}{\underline{89}}$ \\
\hline \multirow[t]{2}{*}{$\begin{array}{l}\text { Polymeric } \\
\text { conjugates }\end{array}$} & $\begin{array}{l}\text { Zinostatin } \\
\text { stimalamer } \\
\text { Conjugate }\end{array}$ & Zinostatin & Yamanouchi & $\begin{array}{l}\text { Primary } \\
\text { unresectabl } \\
\text { e } \\
\text { hepatocellul } \\
\text { ar } \\
\text { carcinoma }\end{array}$ & $\begin{array}{l}\text { Approved } \\
\text { in Japan } \\
1993\end{array}$ & Resource \\
\hline & $\begin{array}{l}\text { CRLX101 } \\
\text { (cyclodextri } \\
\text { n } \\
\text { adamantane } \\
\text { ) }\end{array}$ & CRLX101Drug & $\begin{array}{l}\text { Cerulean Phar } \\
\text { ma Inc. }\end{array}$ & $\begin{array}{l}\text { Rectal } \\
\text { Cancer }\end{array}$ & Phase II & NCT02010567 \\
\hline
\end{tabular}


Table 4. Continued...

\begin{tabular}{|c|c|c|c|c|c|c|}
\hline & $\begin{array}{l}\text { Crlx101 (cer } \\
\text { ulean) }\end{array}$ & $\begin{array}{l}\text { Crlx101 (cerulean) } \\
\text { bevacizumab }\end{array}$ & $\begin{array}{l}\text { Abramson } \\
\text { cancer center } \\
\text { of the } \\
\text { university of } \\
\text { pennsylvania }\end{array}$ & $\begin{array}{l}\text { Renal cell } \\
\text { carcinoma }\end{array}$ & Phase I & NCT01625936 \\
\hline & $\begin{array}{l}\text { CRLX101, a } \\
\text { cyclodextrin } \\
\text { Olaparib }\end{array}$ & $\begin{array}{l}\text { CRLX101 } \\
\text { Olaparib }\end{array}$ & $\begin{array}{l}\text { National } \\
\text { Cancer } \\
\text { Institute (NCI) }\end{array}$ & $\begin{array}{l}\text { Urothelial } \\
\text { cancer, } \\
\text { NSCLC } \\
\text { SCLC, } \\
\text { prostate } \\
\text { Cancer }\end{array}$ & $\begin{array}{l}\text { Phase I } \\
\text { Phase II }\end{array}$ & NCT02769962 \\
\hline & $\begin{array}{l}\text { XMT1001 } \\
\text { (fleximertm) }\end{array}$ & Camptothecin & $\begin{array}{l}\text { Mersana } \\
\text { Therapeutics }\end{array}$ & $\begin{array}{l}\text { Small Cell } \\
\text { Lung } \\
\text { cancernon- } \\
\text { small Cell } \\
\text { Lung } \\
\text { Cancer }\end{array}$ & Phase I & NCT00455052 \\
\hline & Срс634 & $\begin{array}{l}\text { Cripec }^{\mathbb{R}} \text { nanopart } \\
\text { icles with } \\
\text { docetaxel } \\
\left(\text { taxotere }^{\mathbb{R}}\right)\end{array}$ & $\begin{array}{l}\text { Cristal } \\
\text { therapeutics }\end{array}$ & $\begin{array}{l}\text { Ovarian } \\
\text { cancer }\end{array}$ & Phase II & NCT03742713 \\
\hline \multirow[t]{5}{*}{$\begin{array}{l}\text { Polymeric } \\
\text { micelles }\end{array}$} & $\begin{array}{l}\text { Genexol- } \\
\text { PMTM }\end{array}$ & Paclitaxel & $\begin{array}{l}\text { Samyang } \\
\text { Biopharmaceu } \\
\text { ticals }\end{array}$ & $\begin{array}{l}\text { Breast } \\
\text { cancer; } \\
\text { Non-small } \\
\text { cell lung } \\
\text { cancer }\end{array}$ & $\begin{array}{l}\text { Approved } \\
\text { in south } \\
\text { Korea } \\
2006\end{array}$ & Resource \\
\hline & $\begin{array}{l}\text { Genexol- } \\
\text { PMTM }\end{array}$ & Paclitaxel & $\begin{array}{l}\text { Samyang } \\
\text { Biopharmaceu } \\
\text { ticals }\end{array}$ & $\begin{array}{l}\text { Gynecologi } \\
\text { c Cancer }\end{array}$ & Phase I & NCT02739529 \\
\hline & Nk105 & Paclitaxel & $\begin{array}{l}\text { Nippon } \\
\text { kayaku co., } \\
\text { ltd. }\end{array}$ & $\begin{array}{l}\text { Breast } \\
\text { cancer nos } \\
\text { metastatic } \\
\text { recurrent }\end{array}$ & Phase III & NCT01644890 \\
\hline & Nc-4016 & $\mathrm{Nc}-4016$ & $\begin{array}{l}\text { Nanocarrier } \\
\text { co., ltd. }\end{array}$ & $\begin{array}{l}\text { Advanced } \\
\text { cancerlymp } \\
\text { homa }\end{array}$ & Phase I & NCT03168035 \\
\hline & Nanoxeltm & Paclitaxel & $\begin{array}{l}\text { Samyang } \\
\text { Biopharmaceu } \\
\text { ticals }\end{array}$ & $\begin{array}{l}\text { Advanced } \\
\text { breast } \\
\text { cancer }\end{array}$ & $\begin{array}{l}\text { Approved } \\
\text { in } 2013 \\
\text { South } \\
\text { Korea }\end{array}$ & $\begin{array}{l}\text { Resource 1 } \\
\text { Resource } 2 \\
\end{array}$ \\
\hline
\end{tabular}

$\begin{array}{llllll}\text { Nanoplatin } & \text { Nanoplatin and } & \text { Nanocarrier C } & \text { Locally } & \text { Phase I } & \text { NCT00910741 } \\ \text { (NC-6004) } & \text { Gemcitabine } & \text { o., Ltd. } & \text { Advanced } & \text { Phase II } & \\ \text { and } & & & \text { and } & \\ \text { Gemcitabin } & & \text { Metastatic } & \\ \text { e } & & \text { Pancreatic } & \\ & & \text { Cancer } & \end{array}$


Table 4. Continued...

\begin{tabular}{|c|c|c|c|c|c|}
\hline $\begin{array}{l}\text { PROMITIL } \\
\text { (Pegylated } \\
\text { liposomal } \\
\text { mitomycin- } \\
\text { C) }\end{array}$ & $\begin{array}{l}\text { Promitil } \\
\text { Capecitabinebev } \\
\text { acizumab }\end{array}$ & $\begin{array}{l}\text { Lipomedix } \\
\text { Pharmaceutica } \\
\text { ls Inc. }\end{array}$ & $\begin{array}{l}\text { Cancersolid } \\
\text { tumormetas } \\
\text { tatic } \\
\text { Colorectal } \\
\text { Cancer } \\
\text { (mcrc) }\end{array}$ & Phase I & NCT01705002 \\
\hline Oncoprex & $\begin{array}{l}\text { FUS1 (TUSC2) } \\
\text { encapsulated } \\
\text { Liposome }\end{array}$ & Genprex, Inc. & $\begin{array}{l}\text { Lung } \\
\text { cancer }\end{array}$ & $\begin{array}{l}\text { Phase I } \\
\text { Phase II }\end{array}$ & NCT01455389 \\
\hline $\begin{array}{l}\text { E7389-e044- } \\
112 \\
\text { (eribulin- } \\
\text { liposomal } \\
\text { formulation } \\
\text { ) }\end{array}$ & Eribulin-lf & Eisai limited & $\begin{array}{l}\text { Solid } \\
\text { tumors }\end{array}$ & Phase I & NCT01945710 \\
\hline $\begin{array}{l}\text { 188Re- } \\
\text { BMEDA- } \\
\text { liposome }\end{array}$ & Radiation & $\begin{array}{l}\text { Institute of } \\
\text { Nuclear } \\
\text { Energy } \\
\text { Research, } \\
\text { Taiwan }\end{array}$ & Tumors & Phase I & NCT02271516 \\
\hline $\begin{array}{l}\text { JVRS-100 } \\
\text { (Cationic } \\
\text { liposome } \\
\text { Plasmid } \\
\text { DNA } \\
\text { complex) }\end{array}$ & JVRS-100 & $\begin{array}{l}\text { Milton S. } \\
\text { Hershey } \\
\text { Medical } \\
\text { Center }\end{array}$ & Leukemia & Phase I & NCT00860522 \\
\hline Lipocurc & $\begin{array}{l}\text { Liposomal } \\
\text { curcumin }\end{array}$ & $\begin{array}{l}\text { Signpath } \\
\text { Pharma }\end{array}$ & $\begin{array}{l}\text { Patients } \\
\text { with } \\
\text { Advanced } \\
\text { Cancer } \\
\text { Who Have } \\
\text { Failed } \\
\text { Standard of } \\
\text { Care } \\
\text { Therapy }\end{array}$ & Phase I/II & NCT02138955 \\
\hline Lipusu $^{\circledR}$ & $\begin{array}{l}\text { Paclitaxel } \\
\text { liposome }\end{array}$ & $\begin{array}{l}\text { Nanjing luye } \\
\text { sike } \\
\text { pharmaceutica } \\
1 \text { co., ltd.) }\end{array}$ & $\begin{array}{l}\text { Breast } \\
\text { cancer }\end{array}$ & Phase IV & NCT02142790 \\
\hline Lipusu $^{\circledR}$ & $\begin{array}{l}\text { Paclitaxel } \\
\text { liposome } \\
\text { Gemcitabine } \\
\text { Cisplatin }\end{array}$ & $\begin{array}{l}\text { Nanjing luye } \\
\text { sike } \\
\text { pharmaceutica } \\
1 \text { co., ltd. }\end{array}$ & $\begin{array}{l}\text { Lung } \\
\text { squamous } \\
\text { cell } \\
\text { carcinoma }\end{array}$ & Phase IV & NCT01994031 \\
\hline Tkm-080301 & $\begin{array}{l}\text { Arbutus } \\
\text { biopharma }\end{array}$ & $\begin{array}{l}\text { Lipid particle } \\
\text { targeting polo- } \\
\text { like kinase } 1 \\
\text { (plk1) for } \\
\text { delivery of } \\
\text { sirna }\end{array}$ & $\begin{array}{l}\text { Colorectal, } \\
\text { Pancreas, } \\
\text { Gastric, } \\
\text { Breast and } \\
\text { Ovarian } \\
\text { cancers } \\
\text { with hepatic } \\
\text { metastase }\end{array}$ & Phase I & NCT01437007* \\
\hline
\end{tabular}


Table 4. Continued...

\begin{tabular}{|c|c|c|c|c|c|c|}
\hline & $\begin{array}{l}\text { Cynviloq } \\
\text { IG-001 } \\
\text { (Paclitaxel } \\
\text { polymeric } \\
\text { micelle } \\
\text { nanoparticl) }\end{array}$ & $\begin{array}{l}\text { Nab-paclitaxel } \\
\text { IG-001 }\end{array}$ & $\begin{array}{l}\text { Sorrento } \\
\text { Therapeutics, } \\
\text { Inc. }\end{array}$ & $\begin{array}{l}\text { Metastatic } \\
\text { Breast } \\
\text { cancerlocall } \\
\text { y Recurrent } \\
\text { Breast } \\
\text { Cancer }\end{array}$ & $\begin{array}{l}\text { Not } \\
\text { Applicabl } \\
\text { e }\end{array}$ & NCT02064829 \\
\hline & $\begin{array}{l}\text { Nanoxel M } \\
\text { (Docetaxel- } \\
\text { PM) }\end{array}$ & $\begin{array}{l}\text { Docetaxel } \\
\text { micelle }\end{array}$ & $\begin{array}{l}\text { Samyang } \\
\text { Biopharmaceu } \\
\text { ticals } \\
\text { Corporation }\end{array}$ & $\begin{array}{l}\text { Head and } \\
\text { Neck } \\
\text { Squamous } \\
\text { Cell } \\
\text { Carcinoma }\end{array}$ & Phase II & NCT02639858 \\
\hline \multirow[t]{4}{*}{$\begin{array}{l}\text { Crystalline } \\
\text { NPs }\end{array}$} & $\begin{array}{l}\text { Nbtxr3 } \\
\text { A } \\
\text { suspension } \\
\text { of nanoparti } \\
\text { cles compos } \\
\text { ed of } \\
\text { hafnium } \\
\text { oxide } \\
\text { crystallites } \\
\text { and } \\
\text { phosphate } \\
\text { groups in an } \\
\text { aqueous } \\
\text { medium }\end{array}$ & Device: nbtxr3 & Nanobiotix & $\begin{array}{l}\text { Head and } \\
\text { neck cancer }\end{array}$ & Phase I & NCT01946867 \\
\hline & Targomirs & $\begin{array}{l}\text { Targeted } \\
\text { minicells } \\
\text { containing a } \\
\text { microrna mimic }\end{array}$ & $\begin{array}{l}\text { Asbestos } \\
\text { Diseases } \\
\text { Research } \\
\text { Foundation/ } \\
\text { Engeneic } \\
\text { Limited }\end{array}$ & $\begin{array}{l}\text { Malignant } \\
\text { Pleural } \\
\text { Mesothelio } \\
\text { a Non- } \\
\text { Small Cell } \\
\text { Lung } \\
\text { Cancer }\end{array}$ & Phase I & NCT02369198 \\
\hline & Sgt-94 & $\begin{array}{l}\text { Rb94 plasmid } \\
\text { DNA in a } \\
\text { liposome with } \\
\text { anti-transferrin } \\
\text { receptor } \\
\text { antibody }\end{array}$ & $\begin{array}{l}\text { Synergene } \\
\text { therapeutics }\end{array}$ & Neoplasm & Phase I & NCT01517464 \\
\hline & $\begin{array}{l}\text { Magnablate } \\
\text { Iron NPs }\end{array}$ & $\begin{array}{l}\text { Magnetic } \\
\text { Nanoparticle } \\
\text { Injection }\end{array}$ & $\begin{array}{l}\text { University } \\
\text { College } \\
\text { London } \\
\text { Hospitals }\end{array}$ & $\begin{array}{l}\text { Prostate } \\
\text { Cancer }\end{array}$ & $\begin{array}{l}\text { Early } \\
\text { Phase I }\end{array}$ & NCT02033447 \\
\hline Protein NPs & Abraxane & $\begin{array}{l}\text { Albumin-bound } \\
\text { paclitaxel }\end{array}$ & $\begin{array}{l}\text { American } \\
\text { Pharmaceutica } \\
\text { 1 Partners, Inc. } \\
\text { / American } \\
\text { Bioscience, } \\
\text { Inc. }\end{array}$ & $\begin{array}{l}\text { Breast } \\
\text { Cancer, No } \\
\text { n-Small } \\
\text { Cell Lung } \\
\text { Cancer, Pan } \\
\text { creatic } \\
\text { Cancer }\end{array}$ & $\begin{array}{l}\text { FDA } \\
\text { Approved } \\
2005\end{array}$ & $\begin{array}{l}\text { Application } \\
\text { No.: } 021660 \\
\end{array}$ \\
\hline
\end{tabular}


Table 4. Continued...

\begin{tabular}{|c|c|c|c|c|c|}
\hline Abraxane & $\begin{array}{l}\text { Nab paclitaxel in } \\
\text { combination } \\
\text { with gemcitabine }\end{array}$ & Celgene & $\begin{array}{l}\text { Metastatic } \\
\text { pancreatic } \\
\text { cancer }\end{array}$ & $\begin{array}{l}\text { EMA } \\
\text { Approved } \\
2013\end{array}$ & $\begin{array}{l}\text { EMEA/H/C/0007 } \\
\underline{78}\end{array}$ \\
\hline Ontak & $\begin{array}{l}\text { Denileukin } \\
\text { diftito }\end{array}$ & EISAI INC & $\begin{array}{l}\text { Cutaneous } \\
\text { T-cell } \\
\text { lymphoma }\end{array}$ & $\begin{array}{l}\text { FDA } \\
\text { Approved } \\
1999\end{array}$ & $\begin{array}{l}\frac{\text { Biologic License }}{\text { Application }} \\
\text { (BLA): } 103767\end{array}$ \\
\hline Ontak & $\begin{array}{l}\text { DENILEUKIN } \\
\text { DIFTITOX }\end{array}$ & EISAI INC & $\begin{array}{l}\text { Cutaneous } \\
\text { T-cell } \\
\text { lymphoma }\end{array}$ & $\begin{array}{l}\text { EMA } \\
\text { Approved } \\
2002\end{array}$ & $\underline{\mathrm{EU} / 3 / 01 / 075}$ \\
\hline $\begin{array}{l}\text { Kadcyla }^{\circledR} \\
\text { KADCYLA } \\
\text { TM (ado- } \\
\text { trastuzuma } \\
\text { b } \\
\text { emtansine) }\end{array}$ & $\begin{array}{l}\text { The humanized } \\
\text { monoclonal } \\
\text { antibody } \\
\text { trastuzumab } \\
\text { covalently linked } \\
\text { to the cytotoxic } \\
\text { agent DM1 }\end{array}$ & Genentech, Inc & $\begin{array}{l}\text { Metastatic } \\
\text { breast } \\
\text { cancer }\end{array}$ & $\begin{array}{l}\text { FDA } \\
\text { Approved } \\
2013\end{array}$ & BLA $125427 / 0$ \\
\hline
\end{tabular}

\begin{tabular}{|c|c|c|c|c|c|c|}
\hline Virosomes & Gendicine $^{\circledR}$ & $\begin{array}{l}\text { Wildtype-p53 } \\
\text { (rad-p53) }\end{array}$ & $\begin{array}{l}\text { Saudi Food } \\
\text { and Drug } \\
\text { Authority }\end{array}$ & $\begin{array}{l}\text { Tumors } \\
\text { which have } \\
\text { mutated } \\
\text { p53 genes }\end{array}$ & $\begin{array}{l}2003 \\
\text { Approved } \\
\text { by } \\
\text { Chinese } \\
\text { State } \\
\text { Food and } \\
\text { Drug } \\
\text { Administr } \\
\text { ation }\end{array}$ & $\underline{\text { Resource }}$ \\
\hline \multirow[t]{3}{*}{ Micelles } & Nk105 & Paclitaxel & Nanocarriertm & $\begin{array}{l}\text { Advanced } \\
\text { stomach } \\
\text { cancer; } \\
\text { breast } \\
\text { cancer }\end{array}$ & Phase III & NCT01644890 \\
\hline & Nc6004 & Cisplatin & $\begin{array}{l}\text { Nanocarrier } \\
\text { co., ltd. }\end{array}$ & $\begin{array}{l}\text { Head and } \\
\text { neck cancer }\end{array}$ & Phase II & NCT03771820 \\
\hline & Paclical & $\begin{array}{l}\text { Paclitaxel } \\
\text { micelles }\end{array}$ & $\begin{array}{l}\text { Oasmia } \\
\text { Pharmaceutica } \\
1 \mathrm{AB}\end{array}$ & $\begin{array}{l}\text { Ovarian } \\
\text { cancer }\end{array}$ & Phase III & NCT00989131 \\
\hline \multirow[t]{2}{*}{ Dendrimer } & $\begin{array}{l}\text { Dendrimer c } \\
\text { onjugated } \\
\text { AZD4320 }\end{array}$ & AZD0466 & AstraZeneca & $\begin{array}{l}\text { Advanced } \\
\text { Solid Tumors } \\
\text { Lymphoma } \\
\text { Multiple } \\
\text { Myeloma } \\
\text { Hematologic } \\
\text { Malignancies }\end{array}$ & Phase I & NCT04214093 \\
\hline & $\begin{array}{l}\text { docetaxel } \\
\text { (DTX)- } \\
\text { dendrimer } \\
\text { conjugate }\end{array}$ & DTXSPL8783 & - & $\begin{array}{l}\text { advanced } \\
\text { solid } \\
\text { tumours }\end{array}$ & Phase I, II & IRAS ID: 204296 \\
\hline
\end{tabular}


During clinical trials, the distribution and effect of drug-induced molecules on the body are examined in two main areas:

1. Pharmacokinetics: The fate of the drug in the body (absorption, distribution, metabolism and excretion) is examined. In other words, the answer to the question "what the body does to the drug?" is given.

2. Pharmacodynamics (also known as toxicodynamics): It examines the pharmacological effect of the drug as well as its side effects. In other words, "what the drug does to the body" is examined.

\section{Altered Pharmacokinetics to Improve Properties}

Drug administered systemically (such as oral or intravenous) is transported to the organ and tissue through the blood circulation via pharmacokinetic processes. The drug molecules that go out from capillary to the tissues show activity when they bind to their targets or receptors in diseased cells. The efficacy of the drug depends on the amount of the drug molecules present in the target tissue.

With classical drug formulations, the active ingredient is carried in the blood either as a free molecule or it is bound to albumin. Due to this, higher distribution of the drug in the tissues is obtained with conventional drug formulations compared to nanomedicines.

The same active ingredient given at the same dose in a nanocrrier as a nanomedicine can accumulate in the diseased tissue more intensely than the conventional drug formulation due to EPR effect, and may have a much higher effect. This reduces the concentration and possible side effects of the drug on healthy tissues.

Nanomedicines are usually covered with PEG and can stay longer than conventional drugs in the blood circulation. They are also less distributed throughout the body, which extends the half-life of the drug. In addition, since nanodrugs are larger in size than the endothelial cell spaces $(<10 \mathrm{~nm})$ in the kidneys, they also differ in their excretion process. Liver metabolism of nanomedicines coated with PEG can also be different from free drugs (Table 5).

In summary, the pharmacokinetic properties (half-life, distribution, elimination, and metabolism) of an active agent in the form of a nanomedicine vary greatly from that of the active ingredient in the form of a free molecule. The use of conventional methods and formulas for the calculation of the PK parameters of nanomedicines may not give accurate results, hence new methods and formulas for nanoparticles need to be developed.

\section{Altered Pharmacodynamics}

Pharmacodynamics is the science that studies the biochemical and physiological effects of drugs on the body and their mechanisms of action. The vast majority of drugs show their effect by interacting with different structures (targets or biomarkers) in the diseased organism. The drug target is usually macromolecule, such as a receptor, found on cell membranes and the vast majority of the target macromolecules are protein structures.

The extend of the drug effect depends on the amount of the drug present in that tissue. As the dose or concentration of the drug increases, the effect it creates also increases, but up to a certain point. Increasing the dose or concentration of the drug after this level, no additional biological response can be obtained, due to receptor saturation (95).

In order to be able to exert the action, the active agent of nanomedicine must first be released in a free and active form in the target site. This process depends on the ability of the nano-carrier to carry the drug molecules without releasing them in blood and release all the drug, either in a controlled way or abruptly, in the target tissue.

As a result, the properties of the nano-carrier can indirectly cause changes in the pharmacological effects of the drug. However, the therapeutic index of the active ingredient given to the body as a well-designed nanomedicine will be much larger because of decrease in toxic effects and high accumulation of the active substance in the target tissue. Table 5 attempts to summarize all of these points.

\section{REFERENCES}

1. Lori A Henderson and Lalitha K Shankar. Clinical Translation of the National Institutes of Health's Investments in Nanodrug Products and Devices. AAPS J, 1-17, 2017. DOI: 10.1208/s12248-0169995-X.

2. Max Boholm and Rickard Arvidsson. A Definition Framework for the Terms Nanomaterial and Nanoparticle. NanoEthics, 10(1):25-40, 2016. DOI: 10.1007/s11569-015-0249-7.

3. Jose Manuel Ageitos, Jo-Ann Chuah, and Keiji Numata, Design Considerations for Properties of Nanocarriers on Disposition and Efficiency of Drug and Gene Delivery, in M. Braddock, (ed) Nanomedicines: Design, Delivery and Detection. The Royal Society of Chemistry, pp. 1-22, 2016. 
Table 5. Pharmacodynamic and Pharmacokinetic Events from Conventional Small Drug Molecule Formulations and Drug Molecules Loaded into a Nano Drug Delivery System (96-100)

Free Small Molecule Formulation Molecules Loaded into Nano Drug Delivery System (Nanomedicines)

\begin{tabular}{|c|c|c|}
\hline \multirow{4}{*}{ 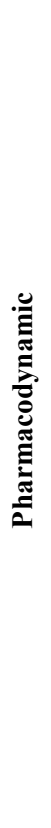 } & $\begin{array}{l}\text { Dispersed throughout the body from application } \\
\text { site and are likely to interact with the cells they } \\
\text { are exposed to. } \\
\text { Their solubility in water and membrane } \\
\text { permeability determine how they reach the } \\
\text { target tissue. }\end{array}$ & $\begin{array}{l}\text { Drug is transported in the carrier for a long time } \\
\text { without release. A major part of the release } \\
\text { occurs in the target organ. While transported in } \\
\text { circulation, the free drug molecule is found much } \\
\text { less than the loaded dose, reducing the drug and } \\
\text { blood cell interaction. }\end{array}$ \\
\hline & $\begin{array}{l}\text { Drug transported from capillary vasculars to all } \\
\text { tissues, and shows its effect by binding to the } \\
\text { receptors in the membrane or inside the target } \\
\text { cells. Off target side-effect is possible. }\end{array}$ & $\begin{array}{l}\text { Upon removal from the vasculature, the } \\
\text { nanomedicine accumulates only in the target } \\
\text { tissue (such as tumor or inflamed tissue). }{ }^{42} \text { Side } \\
\text { effects are minimized. }\end{array}$ \\
\hline & $\begin{array}{l}\text { Activity of the drug depends on the } \\
\text { concentration present in that tissue. Drug } \\
\text { amount reaching the target tissue is small due to } \\
\text { wide biodistribution plus the metabolic and } \\
\text { enzymatic reactions. }\end{array}$ & $\begin{array}{l}\text { Drug molecules in the nano drug delivery } \\
\text { systems are protected from most metabolic and } \\
\text { enzymatic reactions, reaching their target and } \\
\text { acting much more effectively. }{ }^{43}\end{array}$ \\
\hline & $\begin{array}{l}\text { Dosage that shows effect (average effective } \\
\text { dose, ED50) in } 50 \% \text { of the population is } \\
\text { determined by considering the change in } \\
\text { genotype enzyme species across the population. }\end{array}$ & $\begin{array}{l}\text { The average effective dose may be lower } \\
\text { because the drug molecules in the carrier can not } \\
\text { interact the genotype enzymes outside of the } \\
\text { target cells. }{ }^{43}\end{array}$ \\
\hline \multirow{4}{*}{ 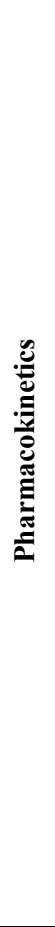 } & $\begin{array}{l}\text { Absorption: Absorption refers to the passage of } \\
\text { drug from the site of administration to blood or } \\
\text { lymph circulation. Based on drug properties, it } \\
\text { can have two mechanisms: passive diffusion and } \\
\text { active transport. }\end{array}$ & $\begin{array}{l}\text { Drug absorption and protection in GI depends on } \\
\text { the properties of the carrier, not the drug. }{ }^{44}\end{array}$ \\
\hline & $\begin{array}{l}\text { Distribution: Drug distribution is dependent on } \\
\text { solubility and generally transported by binding } \\
\text { to large proteins such as albumin. }\end{array}$ & $\begin{array}{l}\text { Nanocarrier provides favorable protective } \\
\text { environment for the drug molecule and prevents } \\
\text { its interaction with neighboring proteins and } \\
\text { other particles in blood. }{ }^{45}\end{array}$ \\
\hline & $\begin{array}{l}\text { Metabolism: Metabolism is chemical conversion } \\
\text { of drug to other substances by the liver or other } \\
\text { tissues. Free drugs may undergo significant first } \\
\text { pass metabolism in the liver leading to decreased } \\
\text { activity. }\end{array}$ & $\begin{array}{l}\text { Nano drug carrier systems and the drug } \\
\text { molecules are metabolized by the enzymatic } \\
\text { reactions after entering the cell through } \\
\text { endocytosis in the target region. }\end{array}$ \\
\hline & $\begin{array}{l}\text { Elimination: Metabolized drugs are excreted in } \\
\text { urine and faces. Some drugs can stay in tissues } \\
\text { for a longer time depending on physicochemical } \\
\text { properties. }\end{array}$ & $\begin{array}{l}\text { In general, the drug and carrier are metabolized } \\
\text { in the target tissue and are excreted through } \\
\text { natural ways. } \\
\text { Opsonization is another way that causes the } \\
\text { nanodrug to be thrown away without reaching } \\
\text { the target. Coating the nanoparticles with PEG } \\
\text { greatly reduces this possibility. In addition, the } \\
\text { size of the nanoparticle must be large enough } \\
\text { not to be eliminated by Glomerular Filtration. }{ }^{46}\end{array}$ \\
\hline
\end{tabular}

4. Volker Wagner, et al. The emerging nanomedicine landscape. Nat Biotechnol, 24(10):1211-1217, 2006. DOI: $10.1038 /$ nbt1006-1211.

5. Silpa Raj, et al. Nanotechnology in cosmetics: Opportunities and challenges. J Pharm Bioallied
Sci, 4(3):186-193, 2012. DOI: 10.4103/09757406.99016.

6. Michihiro Iijima, et al. Core-Polymerized Reactive Micelles from Heterotelechelic Amphiphilic Block Copolymers. Macromolecules, 32(4):1140-1146, 1999. DOI: $10.1021 / \mathrm{ma9815962.}$ 
7. Jae Hyung Park, et al. Polymeric nanomedicine for cancer therapy. Prog Polym Sci, 33(1):113-137, 2008. DOI: 10.1016/j.progpolymsci.2007.09.003.

8. Hayat Önyüksel and Fatemeh Bahadori, Tümör Tedavisinde Hedeflendirilmiş Nanotaşıyıcılar, in Z. Gursoy, (ed) Farmasötik Nanotaşıyıcılar ve Uygulamaları. Kontrollü Salım Sistemleri Derneği, Istanbul, 2013.

9. Sebastian Caban, et al. Nanosystems for drug delivery. OA Drug Design \& Delivery, 2(1):2, 2014.

10. Abolfazl Akbarzadeh, et al. Liposome: classification, preparation, and applications. Nanoscale Res Lett, 8(1):102, 2013. DOI: 10.1186/1556-276X-8-102.

11. Theresa M. Allen and R. Cullis Cullis. Liposomal drug delivery systems: from concept to clinical applications. Adv Drug Deliv Rev, 65(1):36-48, 2013. DOI: $10.1016 /$ j.addr.2012.09.037.

12. Rampal Rajera, et al. Niosomes: a controlled and novel drug delivery system. Biol Pharm Bull, 34(7):945-953, 2011. DOI: 10.1248/bpb.34.945.

13. Gregory Gregoriadis and Brenda E. Ryman. Liposomes as carriers of enzymes or drugs: a new approach to the treatment of storage diseases. Biochem J, 124(5):58P, 1971. DOI: 10.1042/bj1240058p.

14. Gregory Gregoriadis. The carrier potential of liposomes in biology and medicine (second of two parts). N Engl J Med, 295(14):765-770, 1976. DOI: 10.1056/nejm197609302951406.

15. Gregory Gregoriadis. The carrier potential of liposomes in biology and medicine (first of two parts). N Engl J Med, 295(13):704-710, 1976. DOI: 10.1056/nejm197609232951305.

16. Tomowo Kobayashi, Shigeru Tsukagoshi, and Yoshio Sakurai. Enhancement of the cancer chemotherapeutic effect of cytosine arabinoside entrapped in liposomes on mouse leukemia L-1210. Gan, 66(6):719-720, 1975.

17. Carl R. Alving, et al. Therapy of leishmaniasis: superior efficacies of liposome-encapsulated drugs. Proc Natl Acad Sci U S A, 75(6):2959-2963, 1978. DOI: 10.1073/pnas.75.6.2959.

18. Gabriel Lopez-Berestein, et al. Liposomal amphotericin B for the treatment of systemic fungal infections in patients with cancer: a preliminary study. J Infect Dis, 151(4):704-710, 1985. DOI: 10.1093/infdis/151.4.704.

19. Alberto Gabizon, et al. Enhancement of adriamycin delivery to liver metastatic cells with increased tumoricidal effect using liposomes as drug carriers. Cancer Res, 43(10):4730-4735, 1983.

20. Georg Hempel, et al. Population pharmacokinetics of liposomal daunorubicin in children. Br J Clin Pharmacol, 56(4):370-377, 2003. DOI: 10.1046/j.1365-2125.2003.01886.x.

21. Gerald Batist. Cardiac safety of liposomal anthracyclines. Cardiovasc Toxicol, 7(2):72-74, 2007. DOI: 10.1007/s12012-007-0014-4.

22. Christine E. Swenson, et al. Pharmacokinetics of doxorubicin administered i.v. as Myocet (TLC D-
99; liposome-encapsulated doxorubicin citrate) compared with conventional doxorubicin when given in combination with cyclophosphamide in patients with metastatic breast cancer. Anticancer Drugs, 14(3):239-246, 2003. DOI: 10.1097/00001813-200303000-00008.

23. Beth Overmoyer, et al. Pegylated liposomal doxorubicin and cyclophosphamide as first-line therapy for patients with metastatic or recurrent breast cancer. Clin Breast Cancer, 6(2):150-157, 2005. DOI: 10.3816/CBC.2005.n.017.

24. Gerald Batist, et al. Reduced cardiotoxicity and preserved antitumor efficacy of liposomeencapsulated doxorubicin and cyclophosphamide compared with conventional doxorubicin and cyclophosphamide in a randomized, multicenter trial of metastatic breast cancer. J Clin Oncol, 19(5):1444-1454, 2001. DOI: 10.1200/jco.2001.19.5.1444.

25. Lyndsay Harris, et al. Liposome-encapsulated doxorubicin compared with conventional doxorubicin in a randomized multicenter trial as first-line therapy of metastatic breast carcinoma. Cancer, 94(1):25-36, 2002. DOI: 10.1002/cncr.10201.

26. Fatemeh Bahadori, et al. A new lipid-based nano formulation of vinorelbine. AAPS PharmSciTech, 15(5):1138-1148, 2014. DOI: 10.1208/s12249014-0146-3.

27. Vladimir P. Torchilin. Micellar nanocarriers: pharmaceutical perspectives. Pharm Res, 24(1):116, 2007. DOI: 10.1007/s11095-006-9132-0.

28. Sok Bee Lim, Amrita Banerjee, and Hayat Önyüksel. Improvement of drug safety by the use of lipid-based nanocarriers. J Control Release, 163(1):34-45, 2012. DOI: $0.1016 / \mathrm{j}$.jconrel.2012.06.002.

29. Tae-You Kim, et al. Phase I and pharmacokinetic study of Genexol-PM, a cremophor-free, polymeric micelle-formulated paclitaxel, in patients with advanced malignancies. Clin Cancer Res, 10(11):3708-3716, 2004. DOI: 10.1158/10780432.ccr-03-0655.

30. Sa-Won Lee, et al. Development of docetaxelloaded intravenous formulation, Nanoxel-PMTM using polymer-based delivery system. J Control Release, 155(2):262-271, 2011. DOI: 10.1016/j.jconrel.2011.06.012.

31. Adnan Azeem, et al. Nanoemulsion components screening and selection: a technical note. AAPS PharmSciTech, 10(1):69-76, 2009. DOI: 10.1208/s12249-008-9178-x.

32. Tharwat Tadros, et al. Formation and stability of nano-emulsions. Adv Colloid Interface Sci, 108109303-318, 2004. DOI: 10.1016/j.cis.2003.10.023.

33. Cai-Xia He, Zhong-Gui He, and Jian-Qing Gao. Microemulsions as drug delivery systems to improve the solubility and the bioavailability of poorly water-soluble drugs. Expert Opin Drug Deliv, 7(4):445-460, 2010. DOI: $10.1517 / 17425241003596337$. 
34. John Carl Panetta, et al. Comparison of native E. coli and PEG asparaginase pharmacokinetics and pharmacodynamics in pediatric acute lymphoblastic leukemia. Clin Pharmacol Ther, 86(6):651-658, 2009. DOI: 10.1038/clpt.2009.162.

35. C. H. Liu and F. Y. Chang. Development and characterization of eucalyptol microemulsions for topic delivery of curcumin. Chem Pharm Bull (Tokyo), 59(2):172-178, 2011.

36. Elena Sánchez-López, et al. Current Applications of Nanoemulsions in Cancer Therapeutics. Nanomaterials (Basel, Switzerland), 9(6):821, 2019. DOI: 10.3390/nano9060821.

37. Jana Pardeike, Aiman Hommoss, and Rainer H. Muller. Lipid nanoparticles (SLN, NLC) in cosmetic and pharmaceutical dermal products. Int $\mathrm{J}$ Pharm, 366(1-2):170-184, 2009. DOI: 10.1016/j.ijpharm.2008.10.003.

38. Yi Zhao and Leaf Huang. Lipid nanoparticles for gene delivery. Adv Genet, 8813-36, 2014. DOI: 10.1016/B978-0-12-800148-6.00002-X.

39. Jingwen Liu, et al. MicroRNA-200c delivered by solid lipid nanoparticles enhances the effect of paclitaxel on breast cancer stem cell. Int $\mathrm{J}$ Nanomedicine, 116713-6725, 2016. DOI: 10.2147/IJN.S111647.

40. Peng Ji, et al. Naringenin-loaded solid lipid nanoparticles: preparation, controlled delivery, cellular uptake, and pulmonary pharmacokinetics. Drug Des Devel Ther, 10911-925, 2016. DOI: 10.2147/dddt.s97738.

41. Kuldeep Rajpoot and Sunil K. Jain. Colorectal cancer-targeted delivery of oxaliplatin via folic acid-grafted solid lipid nanoparticles: preparation, optimization, and in vitro evaluation. Artif Cells Nanomed Biotechnol, 46(6):1236-1247, 2018. DOI: 10.1080/21691401.2017.1366338.

42. Elham Abbasi, et al. Dendrimers: synthesis, applications, and properties. Nanoscale Res Lett, 9(1):247, 2014. DOI: 10.1186/1556-276X-9-247.

43. Yiyun Cheng and Tongwen Xu. The effect of dendrimers on the pharmacodynamic and pharmacokinetic behaviors of non-covalently or covalently attached drugs. Eur J Med Chem, 43(11):2291-2297, 2008. 10.1016/j.ejmech.2007.12.021.

44. J. M. Caster, et al. Investigational nanomedicines in 2016: a review of nanotherapeutics currently undergoing clinical trials. Wiley Interdiscip Rev Nanomed Nanobiotechnol, 9(1), 2017. DOI: 10.1002/wnan.1416.

45. Khuloud T. Al-Jamal, et al. Cationic poly-L-lysine dendrimer complexes doxorubicin and delays tumor growth in vitro and in vivo. ACS Nano, 7(3):1905-1917, 2013. DOI: 10.1021/nn305860k.

46. Liang Han, et al. Plasmid pORF-hTRAIL and doxorubicin co-delivery targeting to tumor using peptide-conjugated polyamidoamine dendrimer. Biomaterials, 32(4):1242-1252, 2011. DOI: 10.1016/j.biomaterials.2010.09.070.

47. In-Hyun Lee, et al. Targeted chemoimmunotherapy using drug-loaded aptamer-dendrimer bioconjugates. J Control Release, 155(3):435-441, 2011. DOI: 10.1016/j.jconrel.2011.05.025.

48. William B. Liechty, et al. Polymers for drug delivery systems. Annu Rev Chem Biomol Eng, 1149-173, 2010. DOI: 10.1146/annurevchembioeng-073009-100847.

49. Nate Larson and Hamidreza Ghandehari. Polymeric conjugates for drug delivery. Chem Mater, 24(5):840-853, 2012. DOI: $10.1021 / \mathrm{cm} 2031569$.

50. Honey Priya James, et al. Smart polymers for the controlled delivery of drugs-a concise overview. Acta Pharm Sin B, 4(2):120-127, 2014. DOI: 10.1016/j.apsb.2014.02.005.

51. Valentina Guarneri, Maria Vittoria Dieci, and PierFranco Conte. Enhancing intracellular taxane delivery: current role and perspectives of nanoparticle albumin-bound paclitaxel in the treatment of advanced breast cancer. Expert Opin Pharmacother, 13(3):395-406, 2012. DOI: 10.1517/14656566.2012.651127.

52. Ye Jin, et al. Development of a novel niosomal system for oral delivery of Ginkgo biloba extract. Int J Nanomedicine, 8421-430, 2013. DOI: 10.2147/ijn.s37984.

53. Dena Tila, et al. pH-sensitive, polymer modified, plasma stable niosomes: promising carriers for anticancer drugs. EXCLI J, 1421-32, 2015. DOI: 10.17179/excli2013-609.

54. Elnaz Asgharkhani, Aazam Najmafshar, and Mohsen Chiani. Artemisinin (ART) Drug Delivery Using Mixed Non-ionic Surfactants and Evaluation of Their Efficiency in Different Cancer Cell Lines. Int J Drug Deliv Technol, 4(04):89-93, 2014. DOI: 10.25258/ijddt.v4i4.8861.

55. Gopalakrishna Pillai. Nanomedicines for Cancer Therapy: An Update of FDA Approved and Those under Various Stages of Development. SOJ Pharm Pharm Sci, 1(2):13, 2014. DOI: 10.15226/23746866/1/2/00109.

56. Glen J. Weiss, et al. First-in-human phase 1/2a trial of CRLX101, a cyclodextrin-containing polymercamptothecin nanopharmaceutical in patients with advanced solid tumor malignancies. Invest New Drugs, 31(4):986-1000, 2013. DOI: 10.1007/s10637-012-9921-8.

57. Shikha Gaur, et al. Preclinical study of the cyclodextrin-polymer conjugate of camptothecin CRLX101 for the treatment of gastric cancer. Nanomed, 8(5):721-730, 2012. DOI: 10.1016/j.nano.2011.09.007.

58. Thomas Schluep, et al. Pharmacokinetics and biodistribution of the camptothecin-polymer conjugate IT-101 in rats and tumor-bearing mice. Cancer Chemother Pharmacol, 57(5):654-662, 2006. DOI: 10.1007/s00280-005-0091-7.

59. Mark E. Davis. Design and development of IT-101, a cyclodextrin-containing polymer conjugate of camptothecin. Adv Drug Deliv Rev, 61(13):11891192, 2009. DOI: 10.1016/j.addr.2009.05.005.

60. Thomas Schluep, et al. Pharmacokinetics and tumor dynamics of the nanoparticle IT-101 from 
PET imaging and tumor histological measurements. Proc Natl Acad Sci U S A, 106(27):11394-11399, 2009. DOI: 10.1073/pnas.0905487106.

61. Yasuhiro Matsumura and Hiroshi Maeda. A new concept for macromolecular therapeutics in cancer chemotherapy: mechanism of tumoritropic accumulation of proteins and the antitumor agent smancs. Cancer Res, 46(12 Part 1):6387-6392, 1986.

62. Jens-Uwe AH Junghanns and Rainer H. Muller. Nanocrystal technology, drug delivery and clinical applications. Int J Nanomedicine, 3(3):295-309, 2008. DOI: 10.2147/ijn.s595.

63. Yi Lu, et al. Developing nanocrystals for cancer treatment. Nanomedicine (Lond), 10(16):25372552, 2015. DOI: $10.2217 / \mathrm{nnm} .15 .73$.

64. Michael R. Harrison, et al. A phase II study of 2methoxyestradiol (2ME2) NanoCrystal ${ }^{\circledR}$ dispersion (NCD) in patients with taxanerefractory, metastatic castrate-resistant prostate cancer (CRPC). Invest New Drugs, 29(6):14651474, 2011. DOI: 10.1007/s10637-010-9455-x.

65. Christophe Le Tourneau, et al. Hafnium oxide nanoparticles NBTXR3 activated by radiotherapy as a new therapeutic option for elderly/frail HNSCC patients. J Clin Oncol, 37(15_suppl):60696069, 2019.2 DOI: 10.1200/JCO.2019.37.15_suppl.6069.

66. Maureen A. Walling, Jennifer A. Novak, and Jason RE Shepard. Quantum dots for live cell and in vivo imaging. Int J Mol Sci, 10(2):441-491, 2009. DOI: 10.3390/ijms 10020441.

67. Livesey David Olerile, et al. Near-infrared mediated quantum dots and paclitaxel co-loaded nanostructured lipid carriers for cancer theragnostic. Colloids Surf B Biointerfaces, 150121-130, 2017. DOI: 10.1016/j.colsurfb.2016.11.032.

68. Tingting Zhao, et al. Fluorescence and drug loading properties of $\mathrm{ZnSe}: \mathrm{Mn} / \mathrm{ZnS}$-Paclitaxel/SiO2 nanocapsules templated by F127 micelles. J Colloid Interface Sci, 490436-443, 2017. DOI: 10.1016/j.jcis.2016.11.079.

69. Xiaoli Cai, et al. pH-Sensitive ZnO Quantum DotsDoxorubicin Nanoparticles for Lung Cancer Targeted Drug Delivery. ACS Appl Mater Interfaces, 8(34):22442-22450, 2016. DOI: 10.1021/acsami.6b04933.

70. Alejandro Montellano, et al. Fullerene C 60 as a multifunctional system for drug and gene delivery. Nanoscale, 3(10):4035-4041, 2011. DOI: 10.1039/c1nr10783f.

71. Tamsyn A Hilder and James M Hill. Carbon nanotubes as drug delivery nanocapsules. Curr Appl Phys, 8(3):258-261, 2008. DOI: 10.1016/j.cap.2007.10.011.

72. Douglas M. Smith, Jakub K. Simon, and James R. Baker. Applications of nanotechnology for immunology. Nat Rev Immunol, 13(8):592-605, 2013. DOI: $10.1038 /$ nri3488.
73. Tatiana Y. Zakharian, et al. A Fullerene-Paclitaxel Chemotherapeutic: Synthesis, Characterization, and Study of Biological Activity in Tissue Culture. J Am Chem Soc, 127(36):12508-12509, 2005. DOI: $10.1021 / \mathrm{ja} 0546525$.

74. Padmaparna Chaudhuri, et al. Fullerenol-Cytotoxic Conjugates for Cancer Chemotherapy. ACS Nano, 3(9):2505-2514, 2009. DOI: $10.1021 / \mathrm{nn} 900318 \mathrm{y}$.

75. Jun Sung Kim, et al. Antimicrobial effects of silver nanoparticles. Nanomedicine, 3(1):95-101, 2007. DOI: 10.1016/j.nano.2006.12.001.

76. Sohyoung Her, David A. Jaffray, and Christine Allen. Gold nanoparticles for applications in cancer radiotherapy: Mechanisms and recent advancements. Adv Drug Deliv Rev, 10984-101, 2017. DOI: 10.1016/j.addr.2015.12.012.

77. Abolfazl Akbarzadeh, Mohammad Samiei, and Soodabeh Davaran. Magnetic nanoparticles: preparation, physical properties, and applications in biomedicine. Nanoscale Res Lett, 7(1):144, 2012. DOI: 10.1186/1556-276X-7-144.

78. Jingwei Shao, et al. Photothermal nanodrugs: potential of TNF-gold nanospheres for cancer theranostics. Sci Rep, 3(1):1293, 2013. DOI: 10.1038/srep01293.

79. Steven K. Libutti, et al. Phase I and Pharmacokinetic Studies of CYT-6091, a Novel PEGylated Colloidal Gold-rhTNF Nanomedicine. Clin Cancer Res, 16(24):6139-6149, 2010. DOI: 10.1158/1078-0432.ccr-10-0978.

80. Emily S. Day, et al. Vascular-targeted photothermal therapy of an orthotopic murine glioma model. Nanomedicine-UK, 7(8):11331148, 2012. DOI: 10.2217/nnm.11.189.

81. Jennifer G. Morton, et al. Nanoshells for photothermal cancer therapy. Methods Mol Biol, 624101-117, 2010. DOI: 10.1007/978-1-60761609-2 7.

82. Jon A. Schwartz, et al. Feasibility study of particleassisted laser ablation of brain tumors in orthotopic canine model. Cancer Res, 69(4):1659-1667, 2009. DOI: 10.1158/0008-5472.can-08-2535.

83. D. Patrick O'Neal, et al. Photo-thermal tumor ablation in mice using near infrared-absorbing nanoparticles. Cancer Lett, 209(2):171-176, 2004. DOI: $10.1016 /$ j.canlet.2004.02.004.

84. Joshua M. Stern, et al. Selective prostate cancer thermal ablation with laser activated gold nanoshells. J Urol, 179(2):748-753, 2008. DOI: 10.1016/j.juro.2007.09.018.

85. Shayne C. Gad, et al. Evaluation of the Toxicity of Intravenous Delivery of Auroshell Particles (GoldSilica Nanoshells). Int J Toxicol, 31(6):584-594, 2012. DOI: $10.1177 / 1091581812465969$.

86. Donald E Owens and Nicholas A Peppas. Opsonization, biodistribution, and pharmacokinetics of polymeric nanoparticles. Int J Pharm, 307(1):93-102, 2006. DOI: 10.1016/j.ijpharm.2005.10.010.

87. Xiaoqian Shan, et al. Influence of PEG chain on the complement activation suppression and longevity 
in vivo prolongation of the PCL biomedical nanoparticles. Biomed Microdevices, 11(6):11871194, 2009. DOI: 10.1007/s10544-009-9336-2.

88. Stefan Zeuzem, Christoph Welsch, and Eva Herrmann. Pharmacokinetics of peginterferons. Semin Liver Dis, 23 Suppl 123-28, 2003. DOI: 10.1055/s-2003-41631.

89. Daniel Bobo, et al. Nanoparticle-Based Medicines: A Review of FDA-Approved Materials and Clinical Trials to Date. Pharm Res, 33(10):23732387, 2016. DOI: 10.1007/s11095-016-1958-5.

90. Prajna Mishra, Bismita Nayak, and R. K. Dey. PEGylation in anti-cancer therapy: An overview. Asian J Pharm Sci, 11(3):337-348, 2016. DOI: 10.1016/j.ajps.2015.08.011.

91. Balak Das Kurmi, et al. Lactoferrin-conjugated dendritic nanoconstructs for lung targeting of methotrexate. J Pharm Sci, 100(6):2311-2320, 2011. DOI: $10.1002 / j p s .22469$.

92. Aparna Dagar, et al. VIP-targeted Cytotoxic Nanomedicine for Breast Cancer. Drug Deliv Transl Res, 2(6):454-462, 2012. DOI: 10.1007/s13346-012-0107-x.

93. Otilia M. Koo, Israel Rubinstein, and Hayat Onyuksel. Role of nanotechnology in targeted drug delivery and imaging: a concise review. Nanomedicine, 1(3):193-212, 2005. DOI: 10.1016/j.nano.2005.06.004.

94. Anita Hafner, et al. Nanotherapeutics in the EU: an overview on current state and future directions. Int
J Nanomedicine, 91005-1023, 2014. DOI: 10.2147/IJN.S55359.

95. Ongun Onaran and Oguz Kayaalp, Reseptörler ve İlaç Reseptör İlişkisi, in S. Kayaalp, (ed) Akılcıl Tedavi Yönünden Tibbi Farmakoloji. Pelikan kitabevi, Ankara, 2012.

96. Andrea Kunzmann, et al. Toxicology of engineered nanomaterials: focus on biocompatibility, biodistribution and biodegradation. Biochim Biophys Acta, 1810(3):361-373, 2011. DOI: 10.1016/j.bbagen.2010.04.007.

97. Sohail Akhter, et al. Nanomedicines as cancer therapeutics: current status. Curr Cancer Drug Targets, 13(4):362-378, 2013. DOI: 10.2174/1568009611313040002.

98. Mei-Chin Chen, et al. A review of the prospects for polymeric nanoparticle platforms in oral insulin delivery. Biomaterials, 32(36):9826-9838, 2011. DOI: 10.1016/j.biomaterials.2011.08.087.

99. Edward A. Swabb, Wei Wei, and M. Gullino Gullino. Diffusion and convection in normal and neoplastic tissues. Cancer Res, 34(10):2814-2822, 1974.

100.Rebecca Solomon and Alberto A Gabizon. Clinical pharmacology of liposomal anthracyclines: focus on pegylated liposomal doxorubicin. Clin Lymphoma Myeloma, 8(1):21-32, 2008. DOI: 10.3816/clm.2008.n.001. 